\title{
The Perception of Light in Plants.
}

BY

\author{
HAROLD WAGER, F.R.S.
}

\section{With Plates XXXI and XXXII, and three Figures in the Text.}

$T^{1}$

HE extremely interesting observations by Haberlandt upon the sense

organs for light in foliage leaves ${ }^{1}$ have stimulated anew the interest in this question which has been taken ever since the discovery of Charles and Francis Darwin, that in grass seedlings 'sensitiveness to light is sometimes confined to a small part of the plant ; and that this part, when stimulated by light, transmits an influence to distant parts, exciting them to bend.' (The Power of Movement in Plants, 420, I880.)

It is now well known that the stimulus which causes the foliage leaves of many plants to place themselves in such a position as to receive the fullest advantage from the incident rays of light, is perceived mainly by the leaf-blade, and that this stimulus is transmitted to the petiole, by which the turning of the leaf is brought about.

The question therefore arises: by what means does the leaf-blade, or the plant for that matter, perceive that it is or is not in the most advantageous position for the incident rays? Haberlandt has attempted to explain how this is brought about. He has shown that in many leaves the upper epidermal cells are shaped like convex or planoconvex lenses, and being filled with a clear sap are able to bring about a convergence of the light rays ; in others, special cells or local thickenings of the cuticle act in the same way. The epidermal cells have a thin layer of protoplasm on their basal walls. When the leaf is at right angles to the light, the central portion of this layer in each cell is illuminated, the peripheral zone remaining dark. Under the microscope this appears as a bright central disk of light on a dark ground (Fig. 7). In oblique illumination, the bright spot of light moves to one side; and this alteration in the position of the light spot, according to Haberlandt, sets up the stimulus which results in the orientation of the leaf into a more favourable position. The evidence for this conclusion is based upon the optical behaviour of the epidermal cells and upon experiments by which the lens function is eliminated.

\footnotetext{
1 Lichtsinnesorgane der Laubblätter, 1905.
}

[Annals of Botany, Vol. XXIII. No. XCI. July, 1909.] 
Various observations which have been made by recent observers to test the truth of this explanation would seem to show that, in many respects, both the morphological and the physiological evidence upon which it is based is unsound; and in any case it appears to me Haberlandt has not sufficiently considered (I) that the orientation of the leaf may be bound up with the absorption of light by the chlorophyll grains, and not with the action of light upon the protoplasmic layer of the epidermal cells, and (2) that the light rays which are brought to a focus in the tissues of the leaf may be functional, in part at any rate, in the more efficient illumination of the chlorophyll grains.

\section{The Optical Behaviour of the Epidermal Cells.}

The various modifications by which, according to Haberlandt, a differential illumination of the basal wall is brought about in the epidermal cells of diaheliotropic leaves may be grouped as follows :-

Type I. Outer wall flat; inner or basal wall curved or angular.

Type II. Outer wall curved; inner wall flat.

Type III. Combination of I and II. Both outer and inner walls curved. As Seefried ${ }^{1}$ points out, Haberlandt does not give this as a separate type, but it is convenient so to regard it.

Type IV. Papillate projections of a portion of the upper cell-wall, which act as lenses. These are included by Haberlandt under papillate epidermal cells.

Type V. Lens-shaped thickenings of portions of the upper cell-wall, which act as lenses.

Type VI. Local light-perceiving organs of various kinds, reduced or rudimentary hairs, special lens cells, oil drops, and tannin-containing receptacles.

To these may perhaps be added the special cases described by Gaulhofer ${ }^{2}$ as :--

Type VII. Flat epidermal cells with very thick walls which bring about a differential illumination of the basal protoplasmic lining layer through the passage of the rays of light from the highly refractive cell-wall into the less refractive cell-sap.

1 Ueber die Lichtsinnesorgane der Laubblätter einheimischer Schattenpflanzen. Sitzungsber. d. k. Akad. d. Wiss. in Wien, cxvi, 1907.

2 Die Perzeption der Lichtrichtung in den Laubblättern mit Hilfe der Randtüpfel, Randspalten und der windschiefen Radialwände. Sitzungsber. d. k. Akad.d. Wiss. Wien, cxvii, pp. I53-90, 1908. 
The curved upper surface of the epidermal cells can be as a rule very easily seen with a pocket lens, as Haberlandt has pointed out is also the case with well-marked papillate cells ; in bright sunlight or near a window a bright spot can usually be seen reflected in the curved surface of each cell. If examined under a low power by reflected light, images of various objects, reflected in the convex surface as in a convex mirror, are visible. Tradescantia fluminensis, Orchis bifolia, Adoxa moschatellina, and many other plants show this clearly.

With the exception of Type I, the differential illumination of the basal wall is always due to convergence. In Type $\mathrm{I}$, where the outer cell-wall is flat, and there are no special thickenings or other contrivances for the convergence of light, the curvature of the inner wall is sufficient, according to Haberlandt, to bring it about. The lateral portions of such a wall are placed obliquely to the incident rays, and are therefore less illuminated than those portions near the middle which are more or less horizontal. How far this arrangement is capable of bringing about a sufficient amount of differentiation to set up an orientation stimulus will be discussed later.

An excellent example of the way in which these convergent rays act in the illumination of the basal wall is seen in Saxifraga Geum. The curved outer walls of the upper epidermal cells have a well-marked papillate projection about the middle of the cell-wall. This, even without a diaphrag'm, produces a clear spot of light on the basal wall (Pl. XXXI, Fig. 7). If the mirror is moved a little to one side, this spot of light moves, and is now not exactly in the centre (Fig. 8). If the mirror is moved still further to one side, the spot of light moves correspondingly further to one side of the cell (Fig. 9). In this plant the light is brought to a focus actually on or very near the basal wall, and, under all circumstances, the differential illumination of the basal wall is very marked; in the majority of plants it is usually not so clear.

As Haberlandt points out (loc. cit., p. 54), the usual case is for the rays of light to be brought to a focus behind (below) the basal wall. The basal wall cuts the converging cone of light so as to give a bright middle region surrounded by a darker field. The further this is from the apex of the cone of light, the larger the middle field, and vice versa. If the diaphragm is taken away, the dark zone becomes narrower, but is always visible. If the focus is in front of (above) the inner wall, then the clear middle field is formed by cutting through the divergent cone of light. In either case, if the mirror is moved laterally, so that the light falls at an angle on the epidermis, the field of light makes a corresponding movement to one side (Figs. 8, 9).

Haberlandt points out (loc. cit., p. 56) that if the diaphragm opening is I $\mathrm{mm}$. and this is at a distance of $5 \mathrm{~mm}$. from the epidermis, a cone of light is admitted which is equal to a circular opening in the woods of a diameter of $\mathrm{I} \mathrm{m}$. at a distance of $5 \mathrm{~m}$. high from the surface of the leaf illuminated. 
Smaller openings in the woodland green would produce a correspondingly smaller cone of light and a smaller middle field.

Cells with a very regular outline, such as occur in Tradescantia fluminensis and Zebrina pendula on both sides of the leaf, the upper epidermal cells of Ligustrum ovalifolium, various Orchidaceae, \&c., may be compared to the corneal facets of the compound eyes of insects. They act as very efficient lenses, and not only bring the light to a focus but are capable of forming clear and distinct images of objects near them. In one case Haberlandt (loc. cit., Pl. IV, Fig. 2) was able to obtain a somewhat indistinct photograph of a microscope stand which was focused upon the basal wall of the cell. Guttenberg ${ }^{1}$ placed a preparation of the epidermis of Adoxa moschatellina firmly under the microscope, and, after removing the mirror and diaphragm, directed the instrument towards various objects. He then saw the images of the objects quite clearly focused through the cells. Similar observations were made with other plants. It is probable that the upper epidermal cells of the majority of ordinary foliage leaves will be found to possess to a greater or less extent this power. I have examined some hundreds of plants, and only in very few has it been absent. Moreover, in the great majority the cells of the lower epidermis, although not in all cases equal to the upper epidermal cells, function in the same way.

By appropriate manipulation with the microscope and the Gordon photo-micrographic apparatus made hy Messrs. Beck, it has been found possible to obtain photographs of a variety of objects through cells both of the upper and lower epidermis of leaves of many species of plants. Among these are portraits from life, reproductions of photographs of various kinds, flowers and other objects direct, and it has even been found possible to photograph trees, houses, and landscapes, and to reproduce simple diagrams in colour on the autochrome plates of Messrs. Lumière.

The methods employed are perfectly simple, and do not call for any special skill in manipulation. A strip of epidermis is sliced off with a razor and floated gently upon a layer of dilute glycerine placed on a thin coverglass. As much of the glycerine as possible is then soaked up with blottingpaper, leaving the layer of epidermis adhering closely to the glass. The upper surface of the epidermis should be kept dry. The cover-glass is then inverted over a damp chamber and placed on the stage of the microscope, so that the upper surface of the epidermis will be nearest the mirror. Remove the sub-stage condenser but retain the diaphragm; place the object to be photographed at some distance from the microscope; whether this should be two or three feet or several hundred yards depends upon the size of the object. Then by means of the plane mirror reflect the image on to the epidermal cells, and examine with a I-inch objective. A clear view

1 Die Lichtsinnesorgane der Laubblätter von Adoxa Moschatellina, L. und Cynocrambe prostrata, Gärtn. Ber. d. d. bot. Gesell., xxiii, p. 265, 1905 . 
of the epidermal cells should be first obtained; then slowly raise the tube of the microscope and the images of the object focused through each of the epidermal cells will gradually come into view. If the images overlap reduce the size of the diaphragm opening until they are clear; in most cases it will be found that an opening of from two to three millimetres is suitable. Now focus the image clearly by means of the special eye-piece supplied with the photo-micrographic apparatus; replace it by the camera, in which a suitable plate has been placed, and expose. The correct exposure must be found by experience; but using a fairly rapid plate with I-inch objective and ocular A (a moderately deep eye-piece) an exposure of from 2 to 30 seconds is sufficient. With higher powers correspondingly longer exposures must be given. Thus with a bright image, using a $\frac{2}{3}$-inch objective and the apochromatic ocular No. 8 of Zeiss and Cadett extra. rapid plates, an exposure of one minute was given.

The following method of mounting the epidermis of Tradescantia fuminensis, or other epidermis which possesses fairly regular lens cells, is useful. Float the strip of epidermis on a 5 per cent. solution of chromic acid for a short time; then transfer it to water. Cover a glass slide with glycerine jelly and allow to cool. Lay the epidermis on it and soak up the superfluous water. The cells will remain in good condition for observation for several hours. As the epidermis dries the outer walls of the epidermal cells sink in and form concave lenses through which images can still be focused, but below instead of above the layer of epidermal cells.

By means of the autochrome plates of Messrs. Lumière, simple colour photographs have been obtained through the epidermal cells of Tradescantia fuminensis and the special lens cells of Mesembryanthemum cordifolium. The objects used were bright-coloured flowers photographed by reflected light, and simple patterns constructed of coloured sheets of gelatine photographed by transmitted light. In bright sunlight in July, using a I-inch objective and a No. 4 eye-piece, an exposure of from 20 to 30 minutes was given, but in a good light, out of the sun, an exposure of $I \frac{1}{2}$ to 2 hours was necessary. The $3 \frac{1}{4} \times 3 \frac{1}{4}$ plates were cut into four $I_{\frac{5}{8}} \times 1 \frac{5}{8}$ plates for this purpose. No difficulty was experienced in the development of these cut plates beyond a slight tendency to frill at the edges of the film where it had been broken across.

A few illustrations produced from some of the photographs obtained are given in the plates which accompany this paper. Fig. I shows a reproduction of a photograph taken through the epidermal cells of Tradescantia fluminensis, and Fig. 6, a photograph of a geometrical figure taken through the cells of Zebrina pendula. In both cases, the image was brought to a focus below the basal walls and the outlines of the cells cannot be seen. Fig. 12 shows images brought to a focus almost exactly upon the basal wall in Zebrina pendula through papillate projections in the middle of the 
curved outer cell-walls. In this case two images are formed at different levels, one by the cell as a whole (Fig. 6), the other by the more or less central papilla in the upper wall of the cell (Fig. I2). If the epidermal cells are focused so that the image formed by this papilla is first of all brought into view, then, as the tube is moved upwards, this disappears, and the image formed by the whole cell appears.

The production of such clear images shows that the epidermal cells are capable of functioning as very efficient lenses. But it is not probable that the plant is capable of perceiving images, nor is such a supposition necessary to Haberlandt's hypothesis. The epidermal cells have very little resemblance to the highly organized eyes of animals, although, as in the case of Fittonia Verschaffeltii, instanced by Haberlandt, in which there is a lensshaped cell at the apex of a larger cell, the two have some analogy to an animal eye in their general arrangement. Haberlandt points out, if we reserve the term 'eye' only for those organs which bring about an image perception, then the foliage leaves and many animals are eyeless. But if the term is extended to include organs capable of perceiving a difference in the intensity of light, then plants must be said to possess eyes.

\section{Cases in which the Lens Cells do not function in Light Perception.}

That the lens function is of very common occurrence is shown not only by the number of instances adduced by Haberlandt, but by many more recent observations, notably those of Seefried (loc. cit.) and Sperlich, ${ }^{1}$ all of which lend support to Haberlandt's hypothesis. On the other hand, there are numerous instances where lens cells and even special cells and local thickenings of the cuticle occur, which can have no special function in the perception of light for the orientation of the leaf.

In the majority of leaves which I have examined, the cells of the under epidermis show a distinct lens action; they produce a less regular convergence than those of the upper epidermis as a rule, but in many cases equally good and clear. Albrecht ${ }^{2}$ has also shown that papillate cells are of common occurrence on the under sides of leaves. This had, however, not escaped Haberlandt's observation. On p. I25 of his chief paper $^{3}$ he refers to it as of frequent occurrence. He states, however, that it cannot be considered as an objection to his hypothesis regarding the function of the upper epidermal cells. All papillate epidermal cells do not necessarily function in this way ; they may serve for very different purposes such as the prevention of wetting of the leaf. But whenever the curved outer wall of the upper epidermal cells is specially clearly marked,

1 Die optischen Verhältnisse in der oberseitigen Blattepidermis tropischer Gelenkpflanzen. Sitzungsber. d. k. Akad. d. Wiss. Wien, cxvi, 1907.

${ }^{2}$ Ueber die Perzeption der Lichtrichtung in den Laubblättern. Ber. d. d. bot. Gesell., xxvi, p. 182,1908 .

3 Lichtsinnesorgane der Laubblätter, 1905. 
as in velvet leaves, or when a specially differentiated small lens is produced, as in Vinca major, \&c., then these contrivances fail completely on the under side. In such cases he considers it is clear, therefore, that these structures are connected with a definite function which is peculiar to the upper epidermis, and this can only be the function of light perception. Moreover, the local sense organs for light (ocelli) are found exclusively on the upper side of the leaf.

Seefried, however, points out (loc. cit.) that in Aquilegia vulgaris optically efficient papillae are found on the outer walls of the epidermal cells of the lower epidermis as well as on the upper. The papillae of the lower epidermis are, however, not so regularly formed, and are placed more excentrically. From this he would seem to imply that they cannot be functional in Haberlandt's sense. So far as my own observations go, this is not the case. The papillae are much the same in structure on both sides, as indeed Seefried's own figure shows; the lower epidermal cells are more irregular in outline than the upper, but in both cases the papillae may be excentrically placed, although not so much so as in Adoxa moschatellina, as figured by Guttenberg (loc. cit.), to which no exception is taken.

In Viscum album, according to Albrecht (loc. cit.), epidermal swellings occur on both sides of the leaf; and he adduces numerous instances in which papillae are found on leaves which do not assume the fixed light position. He also shows that special cells or groups of cells (ocelli) may occur on the under sides of leaves.

Haberlandt's contention, that special lens cells or lens thickenings fail completely on the under sides of the leaves, therefore falls to the ground, as also does his conclusion that they are specially adapted for the perception of light. Two other examples which show this very clearly may here be given. In Mesembryanthemum cordifolium we have an excellent example of local lens cells. The leaves and stem of this plant are covered with glistening spots which can be quite easily seen by the naked eye. On the leaves these consist of enlarged epidermal cells, more or less regular in outline (Fig. 2) and of a biconvex shape in section; on the stem they are in the form of spherical cells, as in the ice-plant, which stand out from the surface. The cells appear to contain a mucilaginous substance, which may occur in the form of bright refractive granules (Fig. 4), and probably serve to store up water. These cells are very efficient lenses (Fig. 5) ; they occur equally on both sides of the leaf and in both cases equally good images can be photographed through them. In Fig. 3 is shown-somewhat indistinctly, owing to the interference of the mucilage granules-a photograph of some houses taken through the cells on the under side of the leaf. Between these large cells there are the much smaller normal epidermal cells. These also bring about a very clear convergence of the light rays (Fig. 4). The leaves always place them- 
selves with the upper surface exposed to and more or less at right angles to the rays of light. In the leaves of Garrya elliptica both the upper and the under epidermal cells are covered by a thick cuticle, in which lensshaped thickenings occur more or less regularly spaced (Fig. 23). These function as very efficient lenses and produce clear spots of light about the level of the basal walls of the epidermal cells. Fig. 24 shows the image of a cross photographed through them. The images formed are equally clear on both sides of the leaf. So far, however, from producing a centric differential illumination of the basal walls of the epidermal cells, they appear to have no definite relation to them. They are sometimes placed in the middle of the cell-wall, but are just as often near one side, and frequently occur just over the partition wall between two cells (Fig. 23). In these circumstances it is difficult to conceive that their function is that of light perception.

If we consider both upper and lower epidermal cells and also orthoheliotropic as well as dia-heliotropic organs, we find that we can distinguish three different forms of cells according to their optical behaviour.

Form I. Cells with more or less regular outline, which bring the incident rays of light to a focal point-spherical or stigmatic lenses.

Form II. Cylindrical cells which bring the rays to a focal line instead of a focal point, and may therefore be designated astigmatic lenses. These occur mainly on orthotropic organs.

Form III. Cells with very wavy or irregular outlines, intermediate between I and II, each one capable of bringing rays of light to a focal point in one or more regions of the cell, and to a focal line in other parts of the same cell. These occur commonly on the under sides of leaves, but are also found occasionally on the upper surface (e.g. Eranthis hyemalis).

In cells with an irregular or wavy outline, such as occur on the leaves of Evanthis hyemalis, Ranunculus Ficaria, Veronica Beccabunga, various species of Anemone, many Ferns, and numerous other plants, a distinct differential illumination can be seen when a small diaphragm opening, 2 to $3 \mathrm{~mm}$., is used. The light area is, however, very irregular (Fig. I 7), and, although not incapable of explanation by Haberlandt's hypothesis, introduces complications in the light perception which the plant must find some difficulty in disentangling. In some cases the variation in curvature of the outer cell-wall results in the formation of two or more bright spots of light in each cell, each of which is capable of forming an image of an object focused through it.

Anything which brings about a state of turgor in transparent cells tends to the development of a more or less spherical or cylindrical form, and the cells may thus become optically active. This occurs in many cases where it can be no question of the lens function being of special 
importance to the plant for light perception. Such are, for example, the cells of the pith of the Rush, cortical cells in the stems of certain plants, cells in the pileus of species of Russula, and various hair cells and gland cells. Turgidity plays a very important part in the growth of plants and especially in the unfolding of leaves. The cells of the epidermis on the concave side of many expanding leaves are more turgid than those on the outer convex side. This is well shown in Hyacinthus romanus. The young leaves just as they appear above ground are very much curved; the outer epidermis exhibits no turgidity whatever; the inner epidermis, on the contrary, is composed of elongated cells which are very strongly turgid and are capable of bringing the rays of light to a focus in the shape of a clearly defined bright line. The same phenomena can be seen in the strongly incurved young leaves of Cyclamen. Both exhibit a pronounced heliotropism in the young state.

In the case of all leaves which remain flat and rigid, the maintenance of a certain amount of turgidity in the epidermal cells is doubtless necessary unless they possess a thick cuticle. It may be suggested, therefore, that possibly the amount of turgidity and the arching of the cell-walls bear some relation to the thickness of the cell-wall and cuticle. In some cases, for example, the leaves show little or no turgidity in their epidermal cells, but their flatness and rigidity are maintained apparently (in part, at any rate) by much-thickened cell-walls. Such leaves may exhibit a very pronounced dia-heliotropism, and yet show no lens action at all (Prumu' lauro-cerasus). Gaulhofer (loc. cit.) has apparently appreciated the importance of this in respect to Haberlandt's theory, and has brought forward a number of observations to show that in such cases a differential illumination can be brought about, which gives similar results to those described by Haberlandt, by refraction of light through the more highly refractive thick cell-walls into the less highly refractive cell-sap.

The greater turgidity of the epidermal cells of many shade plants may be due largely to their thinner cell-walls and to the fact that they have probably more water to store up owing to their diminished transpiration. Haberlandt refers to turgidity (loc. cit., p. I26) in speaking of aphotometric leaves, but considers apparently that it is of little importance. If, he says, such leaves possess either an arched outer or inner wall in their epidermal cells, we should only perceive in them those physiologically unimportant early stages due to turgor which formed the starting-point in euphotometric leaves of their adaptation to light perception. The problem, however, is one which deserves a much fuller investigation from this point of view than has yet been given to it.

The papillate epidermal cells of many petals show a very distinct light convergence, and are capable of bringing about a very clear centric illumination of the basal walls (Fig. I8). This is well seen in a large number of 
plants, but there is no evidence that it plays any part in orienting the flower with respect to the light.

\section{Dia-heliotropic Leaves which do not possess Contrivances for Centric Differential Illumination.}

Albrecht (loc. cit.), on the ground of numerous observations on the microscopic structure of the epidermis, comes to the conclusion that in many cases, in the absence of contrivances for light perception, the leaves are still found to assume the fixed light position. Haberlandt, ${ }^{1}$ however, considers that all the cases cited by Albrecht which he examined have contrivances for differential illumination of the basal wall, and are thus capable of light perception.

The problem to be determined, however, is not merely the presence of curved outer or inner walls to the epidermal cells, but to what extent these are capable under normal conditions of producing a definite and visible differential central illumination. In the case of markedly papillate cells where the rays of light are actually brought to a focus on or very near the basal walls, the central brighter area of illumination is quite clear and distinct, but in a very large number of plants the focus of the rays is so far below the basal wall that although theoretically a differentiation is possible, in practice, even with the most careful illumination, no such differentiation is observed. Thus in Saxifraga hirsuta or S. Geum, the papilla on the upper surface of the cell produces a very distinct spot of light, whether the diaphragm is open or no, and a corresponding irregular illumination of the field when the light is oblique. Figs. 7, 8, 9, show this. In Tradescantia fluminensis, on the other hand, no differentiation of the lower wall can be observed when the light is perpendicular (Figs. I3, 14). When oblique, one side of the wall is illuminated, the other dark (Fig. I6). This would of course be sufficient to explain the orientation, but in a slightly different manner from that given by Haberlandt. When the leaf is at right angles to the incident light, the whole of the basal protoplasm is equally bright; there is no differentiation into a light central spot surrounded by a darker zone, and, consequently, there is no necessity to regard different portions of the cytoplasmic layer as sensitive to light of varying intensities. The whole of the basal plasma layer may be regarded as attuned to light of higher intensity and no part of it to darkness. When one portion of it is illuminated whilst the other remains dark, as in the case cited (see Fig. I6), this variation may act as the stimulus by which the orientation is brought about. It occurs much more commonly than the centric illumination required in Haberlandt's hypothesis, and will probably be found very widely distributed among plants

1 Ueber die Verbreitung der Lichtsinnesorgane der Laubblätter. Sitzungsber. d. k. Akad. d. Wiss. Wien, mathem.-naturw. Klasse, cxvii, 1908. 
which possess only a slight or moderate curvature of the outer walls. It is, however, only a variation on Haberlandt's hypothesis.

But there are numerous other leaves mentioned by Haberlandt, and of which some instances are given by Albrecht, where the outer wall is flat or only very slightly curved, but the inner wall distinctly angular or arched, which assume a distinctly dia-heliotropic position under the influence of light, and are more difficult to explain. In these cases, Haberlandt assumes that a sufficient amount of light differentiation would be brought about by the difference in the area covered by the rays of light passing through the cell, and impinging on the lower wall. If the lateral walls were very steep, there might be a perceptible difference; but in all the cases which I have examined they show absolutely no light differentiation at all under the microscope. Even when the light falls obliquely there is no differential illumination. The illumination becomes less bright equally all over the basal wall so far as can be observed under the microscope, and as the light becomes more and more oblique, and more of it is reflected from the surface, the basal wall becomes less and less bright, until finally the light is so oblique that none of its rays is able to penetrate the cell.

The number of species in which epidermal cells of the kind just described are found is probably small. The following are a few examples of such leaves, which possess flat-walled or only very slightly curved epidermal cells: Hedera helix, Prumus lauro-cerasus, Buxus sempervirens, Rhododendron, Berberis vulgaris, and Ilex aquifolium. In the majority of other plants which I have examined, the outer walls of the epidermal cells are curved to some extent and therefore capable of causing, in an oblique light, an unequal illumination of the basal wall.

In Hedera helix, according to Haberlandt, ${ }^{1}$ the upper epidermal cells of the leaf are even, but in consequence of the presence of a somewhat uneven cuticle are not quite flat. He states that the inner walls of the cells are more or less angular or arched, and that about 24 per cent. possess the structure suitable to a differential illumination, and only these cells are able to perceive precisely changes in the direction of light. The leaf is clearly dia-heliotropic, but although I have examined a large number of specimens I have not been able to observe any differential illumination capable of demonstration under a microscope. If it exists, therefore, it must be extremely small, and can only be inferred from the cell structure as Haberlandt has done.

In Prumus lauro-cerasus, the most careful microscopic examination, both with and without a diaphragm, fails to reveal anything in the nature of a differential illumination. Fig. IO shows this clearly. The basal walls were clearly focused; the lateral walls are thick and the illumination is seen to be equal all over the cell. The same results were obtained in the other species mentioned.

1 Lichtsinnesorgane, \&c., I905. 
In all these cases, therefore, both Haberlandt's hypothesis, and the variation of it which I have brought forward above, fail to account for the orientation of the leaf.

\section{Ortho-heliotropic Organs.}

The epidermal cells of many ortho-heliotropically sensitive organs show a pronounced optical activity. They are usually elongate, more or less cylindrical cells, and in consequence bring a beam of light to a focal line instead of a focal point. It will be convenient to speak of them as astigmatic lens cells. They are, however, probably not functional in light perception. Some of the most sensitive heliotropic organs do not possess them. They frequently occur on leaves which do not show any heliotropic sensitiveness; in some cases such leaves even possess clearly marked and optically active papillae or lens-shaped thickenings of the cuticle.

C. and F. Darwin point out (loc. cit.) that the exciting cause of the light response in positively heliotropic organs, such as seedlings, is the difference in illumination of the two sides. Haberlandt also considers that this is sufficient to account for the stimulus, and that in consequence no special light-perceiving cells or cell groups are necessary. The observations which I have made, although they show that optically active epidermal cells frequently occur, tend to confirm this view.

In grasses the leaf-blade shows very little if any sensitiveness to light, but, as is well known, the young seedlings are strikingly heliotropic. According to Figdor $^{1}$ the first sheathing leaf or cotyledon and the basal sheathing portions of the leaves are entirely responsible for the response observed in grass seedlings. The epidermal cells on both sides of the leafblade of Avena sativa and the inner epidermal cells of the cotyledon exhibit a very pronounced and beautiful astigmatic convergence (Fig. 22); the outer walls at the ends of the cells are slightly more curved, and are capable of forming clear images, such as those of a pipe, shown in the figure. The epidermal cells on the outside of the cotyledon, which are the only ones exposed to the light, are, on the other hand, optically inactive.

The aphotometric leaves of Glyceria fluitans possess well-marked papillate upper epidermal cells. These papillae occur near the end of each cell and produce very clear spots of light on the basal walls. Their function is, however, to prevent the wetting of the leaf and apparently has nothing to do with heliotropic activity.

The cells of both the upper and lower epidermis of Deschampsia caespitosa show a well-marked convergence due to long astigmatic lens cells. The leaves are aphotometric : they spread out and bend downwards

1 Ueber Heliotropismus und Geotropismus der Gramineenblätter. Ber. d. d. bot. Gesell., xxiii, I905. 
so as to expose their upper surfaces to the light, but this appears to be due to epinastic growth.

The young leaves of Hyacinthus romanus grow towards the light if they are subjected to a lateral illumination. They have a dorsi-ventral structure and soon begin to bend outwards and downwards so as to present their upper surfaces to the light. This appears to be due to epinastic growth, and by its means the leaf is brought into such a position that its upper surface is more or less at right angles to the rays of incident light. The upper epidermal cells are optically active and converge the light as in Iris (Fig. 20). The lower surface, which is the only one exposed to the light when the leaves are heliotropically responsive in the early stages, possesses elongate cells which are flattened and show no trace of convergence.

The hypocotyls of the seedlings of many dicotyledons and the leafstalks of many leaves, such as Ranunculus Ficaria, Evanthis hyemalis, Cyclamen, \&c., all of which are heliotropically responsive, possess welldeveloped astigmatic lens cells similar to those already described (Fig. 20).

Young buds of various bulbous plants, such as Chionodoxa, Tulip, Freesia, \&c., are heliotropically sensitive, but the adult leaves of these plants, although they possess well-marked optically active cylindrical cells, are not, or only very slightly, sensitive to light.

In Freesia refracta, var. alba, the young sheathing leaves bend strongly towards the light. The leaf-blade is not heliotropically sensitive and grows in the direction in which it issues from the bud. As in Grasses, the young sheathing leaves and the basal sheathing position of the ordinary leaves are resposible for the heliotropic response. The epidermal cells of all parts of the adult leaf and the sheathing leaves show a very distinct differential illumination of the basal walls due to thickenings of the cuticle. On the basal sheathing part of the leaf and on the outer sheath leaves the epidermis, both on the inner and the outer surface, consists of elongate astigmatic cells, which have an elongate cuticular thickening in the middle of the outer wall of each cell. In the upper non-sensitive parts of the leaf, there are, instead of these elongate cuticular thickenings, one to three lens-shaped thickenings of the cuticle in each cell which produce clear circular spots of light on the basal walls. These are quite as well developed and as clearly marked as in many of the special cases described by Haberlandt, but are not functional as lightperceiving organs.

\section{Aphotometric Leaves.}

If it could be shown that aphotometric leaves were destitute of lightconverging epidermal cells, it would be distinctly favourable to Haberlandt's hypothesis. Only one case is, however, adduced by Haberlandt (loc. cit., '05, 
p. I26), and this does not appear to hold good for all specimens. $\mathrm{He}$ states that the leaves of Convallaria majalis are aphotometric, and that both the inner and outer walls of the epidermal cells nearly perfectly even. This apparently implies that they have little power of light convergence. I find, however, that this is not so; the cells of the upper epidermis, in all the specimens which I have examined, act as cylindrical lenses, and show an unmistakable convergence (Fig. 2I) which, in an oblique light, is capable of producing a very definite variation in the illumination of the basal walls.

The leaves of Iris, Gladiolus, Montbretia, Tradescantia virginica, and numerous other plants possess elongate cylindrical lens cells capable of bringing the light rays to a focal line, but appear not to be heliotropically sensitive.

In support of Haberlandt, Seefried (loc. cit., p. I7) has some interesting observations on Pirola secunda and $P$. chlorantha. Both species often occur near one another in the shade of woods. The leaf-blade of $P$. secunda is pan-photometric and turns irregularly towards the light on both sides. $P$. chlorantha, on the other hand, is euphotometric, and takes up the fixed light position. The latter is clearly dorsi-ventral with well-developed palisade tissue; the upper epidermis has biconvex lens-shaped cells ; the cells of the lower are flattened. In $P$. secunda the leaf is iso-lateral with no, or only slightly developed, palisade tissue and flattened epidermal cells, a few only of which show any light convergence.

Many Fern leaves, which appear to possess no power of response to light, show in their epidermal cells a distinct and often very beautiful convergence, capable of producing in oblique light a distinct difference in the illumination of the basal walls of the cells.

The only leaf known to me which is aphotometric, and does not possess epidermal lens cells, is Aspidistra lurida. The cell-walls, both inner and outer, are quite flat, and the outer wall is very thick. They appear not to have any power of causing a differential illumination. In many of the cells, however, there is another means by which this can be brought about. Such cells occur generally in groups, and are not visible over all parts of the leaf. Each cell contains a well-marked finely punctate nucleus more or less spherical in shape, generally lying on the lower wall. Its diameter is about $\frac{1}{2}$ to $\frac{2}{3}$ that of the cell itself. Sometimes it is at one end of the cell sometimes near the middle. It is more highly refractive than the substances around it, and is capable of causing the convergence of light rays and of producing bright spots of light. Images can be focused through the nuclei, and with care photographs can be obtained (Fig. II). We have here an efficient apparatus for convergence of light, but it is obvious that it is not functional in any way in causing the orientation of the leaf.

In the leaves of the Carnation (Dianthus Caryophyllus) both the upper 


$$
\text { Wager. - The Perception of Light in Plants. }
$$

epidermal cells and the lower show a convergence, due partly to the slightly arched outer and inner walls, partly to an irregular sculpturing in the middle region of the outer wall. This produces a number of little spots and lines of light which unite together to form a more or less homogeneous band of light which falls on the lower wall. The position which the leaves take up is, however, as C. and F. Darwin have shown (loc. cit., p. 269), probably mainly due to epinastic growth, and seems 'to be very little affected by geotropism or heliotropism'.

\section{EXPERIMENTAL OBSERVATIONS.}

The experimental observations upon which Haberlandt's hypothesis are based consist in the elimination of the lens function either by submerging the leaf in water, or by covering the surface of the leaf with a layer of water under a thin strip of mica. In all cases where the leaf was properly wetted and the lens function eliminated, Haberlandt found that the heliotropic movements were inhibited (loc. cit., I905). In Tropaeolum majus the leaves have a waxy covering which prevents wetting, and thus allows the lens function to be maintained even when submerged; the leaves are, under these conditions, still able to respond to the light stimulus. If the surface of the leaf is washed in dilute alcohol, however, it is easily wetted; its lens function is eliminated, and it no longer responds to the light. These experiments appear to be conclusive, but more recent observations show that leaves do not always behave in this way, and that some other factors than the elimination of the lens function must be taken into account in explaining the loss of heliotropic response.

Fitting ${ }^{1}$ suggested that possibly some deep-seated disturbance in the life of the plant had been brought about by the water. Haberlandt, ${ }^{2}$ however, showed that a leaf wetted on the under side exhibited no loss of power to reach the fixed light position. This does not prove that some modification may not be brought about by the contact of water with the upper surface. That it is extremely important the leaf should not remain wet for any length of time is seen in the very perfect arrangements, such as waxy bloom, smooth epidermis, \&c., for preventing it. Haberlandt ${ }^{3}$ himself shows that when a leaf has been covered with water for some time, it is either not able to gain its power of response to light, or only imperfectly, although the lens function remains as good as ever.

In a later experiment with leaves of Tropaeolum majus. Haberlandt ${ }^{4}$ found, however, that when the upper surface only of the leaf was wetted he

${ }^{1}$ Bot. Zeit., I906.

${ }^{2}$ Die Bedeutung der papillösen Laubblattepidermis für die Lichtperzeption. Biol. Centralbl., xxvii, $297,1907$.

${ }^{3}$ Ein experimentaler Beweis für die Bedeutung der papillösen Laubblattepidermis als Lichtsinnesorgan. Ber. d. d. bot. Gesell., xxiv, 36I -6 , 1906 ; and Bedeutung, \&c., p. 297.

${ }^{4}$ Bedeutung, \&c., p. 300. 
got a distinct turning towards the fixed light position. This, he explains, is due to the fact that the inner walls of the cells are curved, and that there was still, therefore, a sufficient light differentiation to produce the given result.

Kniep ${ }^{1}$ eliminated the lens function by covering the leaf with a thin layer of paraffin oil under a thin sheet of mica or a thin piece of paper. The refractive index of the oil $(\mathrm{I} \cdot 476)$ is greater than that of water, and tends to produce a divergence of the light rays instead of a convergence, and in some cases he obtained, instead of a bright central spot of light, a dark central area and a lighter peripheral zone. Notwithstanding this, the leaves responded to the light stimulus just as ordinary leaves.

I find that this reversion of the differential illumination only takes place when the lens function is very pronounced. It is very easily seen in Saxifraga Geum, which produces under normal conditions a very marked central spot of light on the basal wall. But it is not visible in Tradescantia fuminerssis, where the epidermal cells, althoughvery efficient as lenses, show no differential illumination on the basal wall.

In discussing the results obtained by Kneip, Haberlandt ${ }^{2}$ points our that, theoretically, the divergence produced by the concave oil layer over the curved wall of the epidermal cell ought still to result in a slightly brighter central region on the basal wall, but that actually what is seen under the microscope is the reversion described by Kniep. The brighter peripheral zone appears to be due to reflection of the outer rays of light by the lateral walls and to the passage of rays through the walls from neighbouring cells. By experiments on leaves of Begonia semperflorens he confirms Kniep's observations. When the leaves are covered with a layer of paraffin oil, they respond to the light just as ordinary leaves; when they are covered with water, however, they cease to respond. It is evident, therefore, according to Haberlandt, that the power to respond, which is maintained in the oil-covered leaf, must still be connected with the differential illumination of the basal wall, although under these conditions it is completely reversed. Instead of, as he formerly suggested, ${ }^{3}$ the central region of the basal protoplasmic layer being attuned or sensitive to light of higher intensity, he now concludes that this sensitiveness cannot be considered as an unchangeable inherent property of the different parts of the plasma layer, but only as an acquired adaptation phenomenon (analogous to the local adaptation of the human retina) capable of modification, when placed under conditions which bring about an inverse illumination.

It is, however, not clear how the plasma layer is able to adapt itself to such extremes, which are unlikely to occur in nature. Moreover, the difference in illumination is nothing like so pronounced with the paraffin oil,

1 Ueber die Lichtperzeption der Laubblätter. Biol. Centralbl., xxvii, 97, 1907.

2 Bedeutung, \&c., p. 289.

${ }^{3}$ Lichtsinnesorgane, \&c. 


$$
\text { Wager.-The Perception of Light in Plants. }
$$

as it is under the normal conditions, and if so marked a difference is required in the one case, it is reasonable to suppose that it would be equally required in the other. From experiments which he has recently made, however, upon the amount of light differentiation required for heliotropic response in plants, Haberlandt ${ }^{1}$ comes to the conclusion that it is sufficient to bring about a response.

Gius ${ }^{2}$ concludes from experiments which he has made upon various seedlings, and upon leaves of dia-heliotropic plants submerged in water, that it is not the perception but the power of movement which is inhibited. The response to light is markedly later and slower than in air. If, however, the submergence in water is limited to the period required for the perception to take place, there is no delay in the motor response. The explanation offered is that the difference in turgor of the cells required to bring about the movement is prevented by the surrounding water. This explanation cannot apply when the surface only of the leaf-blade is covered with water. But it is possible that even here the water may produce some change in the leaf, even if only a very slight one, detrimental to the perception of light or to the motor reaction. It is quite possible that leaves may vary in their power to resist the detrimental action of water, as indeed is seen in water plants and those grown in marshy places, as compared with plants normally accustomed to drier conditions, and which, when submerged in water, soon begin to decay.

Haberlandt ${ }^{3}$ shows that even when covered with water the highly curved or pyramidál epidermal cells still maintain the power to some extent of light differentiation. In cells in which the outer wall is less curved, but still moderately strongly curved, as in Tropaeolum Lobbianum, the whole basal wall is equally illuminated when covered with water, but in oblique light a distinct differentiation can be observed. Under such conditions the orientation of the leaf would still take place when submerged in water, but not so perfectly or so quickly as in air.

Haberlandt describes (loc. cit., I909) some interesting experiments in which separate parts of the upper surface of a single leaf were illuminated from opposite sides by equal light, one half of the leaf being covered with a layer of water, the other half dry. With almost equal illumination from opposite sides of corresponding parts of the leaf, and with the wetted part of the leaf 2.2 to 4.8 times as large as the dry part, the inclination of the lamina towards the light was always in the direction of the dry part of the leaf. If the two halves of the leaf were of equal size and the wetted half twice as strongly illuminated as the dry half, the leaf still turned in the direction of the dry half of the leaf, that is, towards the weaker light. The experi-

1 Zur Physiologie der Lichtsinnesorgane der Laubblätter. Jahrb. f. wiss. Bot., xlvi, 377, 1909.

${ }^{2}$ Ueber den Einfluss submerser Kultur auf Heliotropismus und die Lichtlage. Sitzungsber. d. k. Akad. Wien, cxvi, r907.

${ }^{3}$ Zur Physiologie, \&c. 
ments were made with Tropaeolum majus. They show clearly enough that in the case of the leaves of this plant the dry leaf is more sensitive to heliotropic stimulation than the wetted leaf; in other words, the leaf in which the lens function is not interfered with is more sensitive than the one in which it is eliminated. This, however, does not prove that the lens function stands in direct causal relation to the heliotropic response. The power to respond when covered with water seems to vary with different leaves, and it is quite probable that the leaves of Tropaeolum majus are sensitive to water in some way which interferes with the heliotropic response other than elimination of the lens function.

Nordhausen ${ }^{1}$ brought about the elimination of the lens action by means of a thin layer of 5 to io per cent. of gelatine spread over the surface of the leaf. As the refractive index ( $\mathrm{I} \cdot 34 \mathrm{I}$ in 5 per cent., $\mathrm{I} \cdot 347$ in $\mathrm{I} 0$ per cent. solution) is very near that of the cell contents, there can be no question of reversed illumination. Experimenting on similar plants to those used by Haberlandt, Nordhausen shows that the response to light is not inhibited, and therefore he concludes that the lens function is not directly connected with the perception of light by the leaf-blade.

Haberlandt (loc. cit., 1909) criticizes Nordhausen's experiments and shows that, as regards the lens function, leaves covered with a 5 to 10 per cent. solution of gelatine behave very much like those covered with water, and therefore in certain cases a light response would be obtained.

From a few experiments which I have made to test the heliotropic response when leaves are submerged in water, results were obtained which seemed to show, when taken in conjunction with those already described by Haberlandt and others, that the evidence on the experimental side is at present so contradictory and unsatisfactory that a very much more complete investigation of the various functions involved will be necessary before any satisfactory conclusions can be arrived at.

Ramunculus Ficaria. A complete plant was submerged in water and exposed to one-sided illumination. The leaf-stalks curved very markedly towards the light, and the leaf-blade was placed more or less at right angles to the falling light rays. The response was just as active and as rapid as in plants not submerged. Leaves removed from the plant did not respond so quickly, but in all young leaves there was a definite response in a few hours. The cells both of the upper and lower epidermis of the leaves are irregular in outline, with both inner and outer walls arched. With a small stop there is a slight differential illumination of the basal walls, but not with an open stop. Below the basal wall is an irregular light area surrounded by a dark one (Fig. I7), with brighter spots here and there where the cellwall was slightly more curved. When the outer wall was covered with water

1 Ueber die Bedeutung der papillösen Epidermis als Organ für die Lichtperzeption der Laubblätter. Ber. d. d. bot. Gesell., xxv, 398, I907. 
no differential illumination of the basal walls was visible. When the leafblade was cut off, the leaf-stalks also curved towards the light, but not so quickly or so definitely as when the leaf-blade was present, and the movement was soon inhibited. These experiments show clearly that, although the lens function is eliminated, the heliotropic response of the leaves of Ranunculus Ficaria is almost as pronounced in water as in air.

Adoxa moschatellina. Both in water and in air, a one-sided illumination causes the leaf-stalk to curve towards the light so as to bring the leaf-blade into a position more or less at right angles to it. The position taken up by the submerged leaves was exactly like that given by Guttenberg in his figure illustrating the heliotropic response of the leaves in air (loc. cit., Fig. 5, Pl. II). In one experiment which I made, a submerged leaf, which had curved sharply to the light, was turned completely round so that its upper surface was turned away from it. Almost immediately a second curvature was induced a little higher up the leaf-stalk, and the leaf again curved towards the light (TextFig. 1). The upper epidermal cells exhibit a beautiful convergence, due to a small projecting papilla in the middle of each outer wall, as Guttenberg (loc. cit.) has shown, which disappears entirely in water.

Saxifraga Geum. The old leaves turn towards the light very slowly in air, but

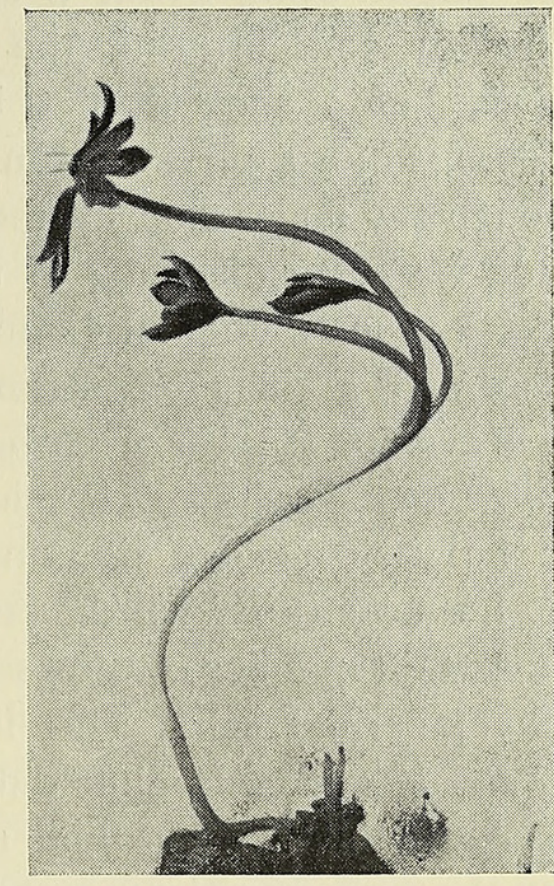

Text-Fig. I. Leaf of Adoxa moschatellina submerged in water and exposed to a one-sided illumination. The double curve is due to the leaf having been completely turned round from its first position and exposed a second time to the light.

in water apparently not at all. The young shoots, in air, turn very markedly towards the light, so as to bring the young leaves into a position more or less at right angles to it, but are not responsive in water. The minute papillate projection in the middle of the outer wall of each of the upper epidermal cells brings about a very distinct bright spot of light on the basal wall, which disappears entirely in water.

In both these plants the lens function disappears entirely in water: there is no differentiation visible even in oblique light, and yet when submerged in water there is a definite heliotropic response in the one, but not in the other. 


\section{The Function of the Lens Cells in the more Efficient Illumination of the Chlorophyll Grains.}

It is clear that the orientation of the leaf with respect to the light has for its main purpose the more efficient illumination of the chlorophyll grains ; and this must be taken into account in considering the lens function of the epidermal cells. Haberlandt ${ }^{1}$ had already in 1882 suggested that they might bring about a more intense illumination of the chlorophyll grains by concentrating the light upon the chlorophyll-containing cells. Later, Stahl ${ }^{2}$ showed that if sunlight is allowed to pass through the epidermis of a somewhat thin leaf, such as Begonia falcifolia, and observed through the under side by means of the microscope, the chlorophyll grains would be seen glistening in the bright concentrated light. Any one who will take the trouble to examine carefully the incidence of light upon the chlorophyll grains after passing through the lens-shaped epidermal cells of the leaves of species of Selaginella, Tradescantia fuminensis, Adoxa moschatellina, Narcissus, Hyacinth, and many other plants will be struck by the very efficient illumination which is observable. As Stahl points out, however (loc. cit.), the concentration of the light would only be useful to a certain number of the assimilating cells, as there may be several under each epidermal cell. This is well seen in Oxalis acetosella. In species of Peperomia, Stahl points out, the light would be brought to a focus in the water-containing tissue, and not on the chlorophyll grains; this indicates that the concentration must have some other purpose. He suggests that the papillate or dome-shaped form of the epidermal cells, which are found in many shade plants, may serve not so much for the concentration of the light as for the purpose of collecting those rays which, coming in a nearly parallel direction to the surface of the leaf, would be reflected from it if the cells were flat. The conical shape of many of the epidermal cells of shade plants would seem to favour this view, and Stahl shows by means of models that the collection of light in this way, and its utilization by the chlorophyll grains, is quite possible. This explanation would hardly hold good, however, in the case of cells which possess only slightly curved outer walls.

The numerous observations which have been made upon Schistostega osmundacea, some Selaginellas, and Hepatica all clearly indicate that in some cases the lens cells are for the purpose of bringing about a concentration of light upon the chlorophyll grains.

The researches of Vuillemin ${ }^{3}$ and Noll $^{3}$ showed this very clearly in

${ }^{1}$ Die physiologischen Leistungen der Pflanzengewebe. Schenk's Handbuch der Botanik, ii, 579,1882 .

${ }^{2}$ Ueber bunte Laubblätter. Ann. du Jardin Bot. de Buitenzorg, xiii, I37, 1896.

${ }^{3}$ L'appareil reluisant du Schistostega osmundacea. Journ. de l'anatomie et de physiologie, vol. xxiii, p. 18, I887; and Noll, Ueber das Leuchten von Schistostega osmundacea, Schimp. Arbeiten 
Schistostega osmundacea. The protonema of this moss, which is found in caves, is luminous. The cells are shaped like a convex lens above, and the chlorophyll grains are found in the basal part of the cells, which is conical. The rays of light which fall upon the cell are refracted and concentrated upon the chlorophyll grains. Owing to the shape of the cell, some of the rays are totally internally reflected from the basal walls of the cell and are again emitted, which gives the luminous appearance. Noll showed also that a variation in the direction of the light rays was accompanied by a corresponding movement of the chlorophyll grains, in order that they might always be in a position to take the fullest advantage of the concentration of the light.

The arrangement of the chlorophyll grains in such plants as Oxalis acetosella, various species of Begonia, and other shade plants favours this view. Schürhoff ${ }^{1}$ has also shown that in some species of Peperomia the upper convex walls of the palisade cells, together with the contained calcium oxalate crystal, act as lenses for the concentration of light on the chlorophyll grains, as well as for light perception.

In Botrydium gramulatum the chlorophyll grains are distributed more or less evenly over the whole interior surface of the nearly spherical cell, the rest of the cell being filled with a clear cell-sap. As the plant grows in shady places, such as roadside ditches and damp clayey soil under trees, and possesses no means of orientation, a portion of the chlorophyll grains would be always in obscurity, if it were not that the spherical shape of the cell brings about a total internal reflection of some of the rays of light which pass into it. In this plant, however, it is not so much the condensation of the light as the more efficient distribution of it that is important.

In leaves with more or less elongate palisade cells, it is also probable that the direct condensation of the rays of light upon the chlorophyll grains is not so important as the more efficient dispersal of them among the chlorophyll grains, due to their being brought to a focus in the palisade cells, instead of passing straight through them, as would be the case if no convergence were possible, as in leaves with flat outer walls.

In those shade plants, and in the species of Peperomia cited by Stahl (loc. cit.), where the rays of light are brought to a focus above (in front of) the cup-shaped or short palisade cells, we should also have, not a condensation of the light rays, but a more efficient distribution of them over the chlorophyll grains, due to their divergence after passing the focal point. This would be the greater owing to the number of different focal points produced, a consequence of the spherical aberration due to the conical shape of the cell.

aus dem botanischen Institut zu Würzburg, iii, 1887. See also W. West, Luminosity of Schistostega osmundacea. Naturalist, 256,1907 .

1 Ozellen und Lichtkondensoren bei einigen Peperomien. Beil. z. bot. Centralbl., xxiii, p. I 4, I 908. 
The evidence before us, therefore, seems to justify the conclusion that in special cases the lens-shaped epidermal cells may be functional in the more efficient illumination of the chlorophyll grains, either by concentrating the light upon them, or by a more efficient dispersal of it among them. It is possible that this may be also bound up with light perception in the manner suggested in the following section.

\section{Chlorophyll Grains as Organs for Light Perception.}

In formulating his hypothesis that it is in the cytoplasm lining the walls of the epidermal cells that the light perception takes place, Haberlandt based it fundamentally upon the statement of Noll (I878), that the outer layer of the cell protoplasm is the seat of sensitiveness for light and gravity. In order to explain this sensitiveness, Haberlandt suggests that it may be due to the mechanical pressure exerted by light. The stimulus set up by the differential illumination of the plasma layer on the basal wall of the epidermal cells would thus be brought about by the difference in pressure between the illuminated and the dark areas. But this must be extremely small. Clark Maxwell showed that, on a perfectly reflecting surface on which the pressure would be the greatest, sunlight should exert a pressure of about 0.8 milligram per square metre, and on a black surface about 0.4 milligram per square metre. As a writer in the Botanical Gazette remarks ${ }^{1}$ : 'The pressure on a cell (from figures calculated by Maxwell and determined experimentally by Nicholls and Hull) $0.01 \mathrm{~mm}$. square in full sunlight would scarcely amount to $7 \times \mathrm{IO}^{-11}$ milligram! To believe that a plant could discriminate between 0 and $0.000,000,000,07 \mathrm{mg}$. pressure makes a severe test of one's credulity.' It is well known that heliotropism depends upon the quality of the light rays, and not merely upon variation in light intensity. The less refrangible rays are important in photosynthesis, the more refrangible rays are more important in growth and formative processes, irritable movements, and curvatures. Haberlandt himself has shown, by the use of chlorophyll screens, that the only rays which are functional in heliotropism are those which are absorbed by the chlorophyll; and, as we know from the researches of Sachs, it is only the more refractive half of the visible spectrum, the blue and violet rays, which produce the stimulus. If it were merely a difference in the illumination, we ought to obtain a result in red or yellow light. ${ }^{2}$ This points to the conclusion that the light perception is bound up with the absorption by the chlorophyll. Haberlandt, indeed, considers this possibility, but dismisses it for the reason that certain plant organs which do not contain chlorophyll are

1 C.R.B. Bot. Gaz., xxxviii, I 57 , 1904.

${ }^{2}$ Cf. E. Pringsheim, junr., Ber. d. d. bot. Gesell., 556, 1908. 
still found to be heliotropically sensitive. He points out, for example, that in Acer Negundo and Cormus sanguinea there are sometimes whole shoots in which the leaves are almost bleached and destitute of chlorophyll. These show, notwithstanding the absence of chlorophyll, in their young stage, a dia-heliotropic response, which is, however, in most cases lost as the leaves become older. The weak point in this argument seems to me to be that, although the leaves are destitute of chlorophyll, they may contain, at any rate in the earlier stages, a certain amount of yellow colouring matter by which the more refractive rays of the visible spectrum would be absorbed, and thus satisfy the requirements for a heliotropic response.

Light is able to bring about an orientation of the chloroplasts in many foliage leaves and in some Algae. Under the influence of too strong or too weak a light, they are brought into more suitable positions, either by turning completely round, as do the chlorophyll bands of Mesocarpus, or by moving into different positions in the cell, as in Elodea, Oxalis acetosella, Schistostega osmundacea, \&c. Just as in the orientation of the leaf itself, the stimulus which brings about the orientation of the chloroplasts is produced by the more refrangible rays of the spectrum absorbed by the chlorophyll.

Light sensitive motile organisms, such as Euglena and the swarm spores of Algae, behave in red light just as they do in the dark, but exhibit pronounced heliotaxis in light blue. This is the more significant as the red spot, which is supposed to function in this heliotactic stimulation, absorbs just those rays which are active. ${ }^{1}$ In these cases, therefore, it is fair to assume that the movement is brought about by absorbed rays and

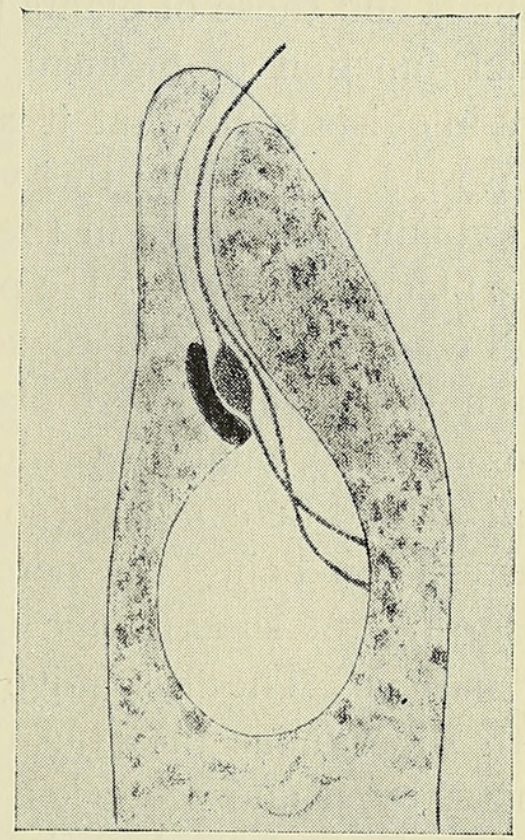

Text-Fig. 2. Side view of the anterior end of a cell of Euglena viridis, showing the flagellum and its enlargement in front of the eye-spot. (From Journ. Linn. Soc. Zool., xxvii, I899.)

not by any kind of mechanical action on the cytoplasm. The association of the spherical or oval swelling on the basal portion of the flagellum in Euglena, with the red pigment-spot (Text-Fig. 2), is analogous to the association of the rods and cones of the animal eye with their pigment layer. The light absorbed by the pigment-spot probably sets up chemical changes which affect the swollen part of the flagellum, and this in turn acts upon the

1 Wager: On the Eye-spot and Flagellum in Euglena viridis. Journ. Linn. Soc. Zool., xxvii, 463, I900. Mast: Light Reactions in Lower Organisms, II. Volvox. Journ. Comp. Neurology and Psychology, xvii. I12, I907. 
flagellum itself, and thus brings about those modifications in its vibrations by which the direction of movement of the organism is regulated.

At the red end of the spectrum, Engelmann has shown that the curve of assimilative activity corresponds very nearly with the curve of absorption ; but at the blue and violet end, a comparison of the two curves shows that the amount absorbed is much greater than can be accounted for by the assimilative activity, and the suggestion may be made that the excess of light absorbed at the blue end of the spectrum is partly functional in heliotropism. This would perhaps partly explain the heliotropic activity of young seedlings, which are of a yellower colour than fully developed leaves, for the yellow colouring matter readily absorbs the blue end of the spectrum.

One important difference between the light-perceiving organs of animals and those of plants is the presence of pigment in the former. The exact function of pigment in the animal eye is still uncertain. Some physiologists think that it serves merely for the absorption of superfluous light rays, and, taking this view, Haberlandt suggests that there is no need to explain its absence in the plant cell, for light perception could very well take place without it. He points out, however, that the chlorophyll grains might act as a screen to keep extraneous light away from the sensitive percipient layer of cytoplasm, and that, in Selaginella Martensii and similar forms, there is a chlorophyll grain at the base of the epidermal cell which could be compared to a pigment layer, the cytoplasm between it and the cell-sap being the percipient organ. But it is doubtful whether the absorption of superfluous light is the sole function of the pigment in the animal eye. The alternative view is that the pigment is not merely concerned with superfluous rays, but that the rays which are active in vision are absorbed by it and produce a chemical change in it, and that it is this change which affects the rods and cones and causes the stimulus of light perception. There is in the eyes of many vertebrates a substance called visual purple, associated with the percipient organs, which is possibly derived from the pigment layer and is very sensitive to light. How far the experiments made by Kühne ${ }^{1}$ and others upon the changes which take place in this pigment may be found to have a bearing upon the problem, we cannot say, but the destruction or bleaching of chlorophyll by light is perhaps somewhat analogous to the changes in colour and bleaching of the visual purple. The most active rays in the bleaching of visual purple are those of the yellow-green part of the spectrum, and these are the rays which are most readily absorbed by the colour itself.

Cannot this be taken as the basis of a more satisfactory hypothesis for light perception in plants? It is difficult to believe that the sensitive

1 On the Photochemistry of the Retina and on Visual Purple. Eng. trans., edited by Sir M. Foster, 1878. See also Text Book of Physiology by Foster and Rivers, Part IV, p. I 369, I900. 
chlorophyll grains, which in some plants show definite movements of orientation in response to light, have no other function in light perception than that of a screen. If the light had a merely mechanical action such as is suggested by Haberlandt, it is difficult to see why the most energetic rays, which are at their minimum in the blue, but rise rapidly to a maximum in the yellowgreen, and extend through the whole of the red and far beyond into the infra red, should not be functional. The rays which are active are, in fact, the chemical rays, and it appears to me to be much easier to explain the heliotropic reaction upon the assumption that it is due to chemical activity than that it should be merely due to mechanical action.

Perhaps the most important and attractive feature of Haberlandt's hypothesis is that it affords, for the first time, a definite explanation of how a plant is able to perceive the right direction in which its leaf must be turned to bring it into the most advantageous position for the illumination of the chlorophyll grains. It is true that he has not brought forward any evidence to show whether the movement takes place at once in the right direction, or whether there is anything in the nature of a trial and error movement on the part of the leaf before the right direction is perceived. From the general trend of his observations we are, I think, led to conclude that the leaf at once perceives and turns in the right direction.

It is an important question, therefore, whether the leaf would be able to orient itself as readily and as surely if the chlorophyll grains were the percipient organs. There seems to be no reason from the evidence available why it should not do so. The chlorophyll grains are probably much more sensitive to light than the protoplasm, and any differential illumination of them would be likely to set up a much more definite stimulus than a differential illumination of the cytoplasm lining the basal walls.

To bring about such a stimulus, an unequal illumination of the chlorophyll grains would be necessary in oblique light. There is no difficulty in seeing that this would be the case (Text-Fig. 3). The passage of rays of light obliquely through the epidermal cells into the palisade tissue would bring about a partial illumination of the chlorophyll grains. The rays of light would be bent on passing into the epidermal cells, and would then pass on in straight lines to and through the palisade cells. The chlorophyll grains on one side of each palisade cell would be more strongly illuminated to an extent depending upon the angle of the incident rays, than those on the other side, which would remain in obscurity, or at least would only be exposed to rays which had already passed through one, and possibly more than one, layer of chlorophyll grains, being thereby much weakened in the active heliotropic rays. This would set up the stimulus required to bring about the orientation of the leaf in a direction at right angles to the incident light, in which position the chlorophyll grains in each palisade cell would be equally illuminated. That this unequal illumination of the chlorophyll 
grains is sufficient to account for a direct movement towards a right position, without the intervention of trial and error movements, is perhaps not so certain as in the cases of clear centric illumination of the basal walls of the epidermal cells described by Haberlandt: but it would take place quite as surely and as readily as in those cases of unequal non-centric differential illumination which, as I have shown (p. 468), occur in a large number of leaves with epidermal lens cells of long focus; and it certainly affords a much more satisfactory explanation for those cases in which the epidermal cells are flat or possess only curved basal walls. It would also enable us to account for those cases in which a heliotropic response takes place when the lens fuction is eliminated. Even if we have to assume a certain amount of trial and error movement before the right direction is perceived, and I am

$$
\text { A } B
$$

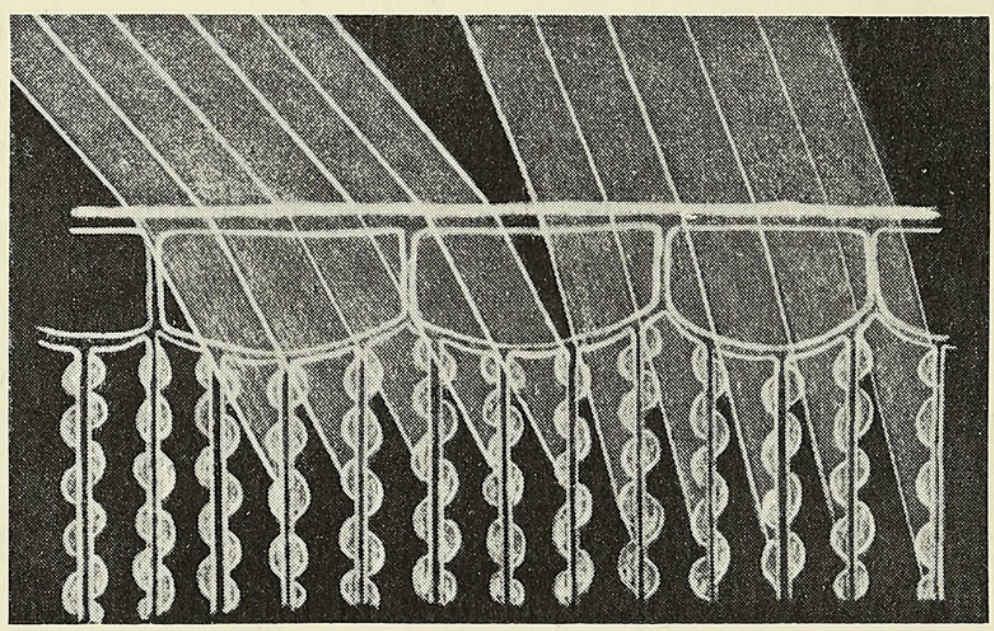

TEXT-FIG. 3. Diagram showing how the chlorophyll grains in the palisade cells of a foliage leaf with flat outer walls would be partially illuminated in oblique light. $A$ and $B$ show the difference in the illumination at different angles of incidence.

not sure that this is not also necessary in Haberlandt's hypothesis, we have a basis for this in the autonomous movements of circumnutation which have been so fully described by Charles and Francis Darwin ${ }^{1}$. They point out (p. 3) that:- ' The movements of various organs to the light, which are so general throughout the vegetable kingdom, and occasionally from the light, or transversely with respect to it, are all modified forms of circumnutation.' And again (p. 4I9)-' Heliotropism seems always to consist of modified circumnutation. Any kind of movement in relation to light will obviously be much facilitated by each part circumnutating or bending successively in all directions, so that an already existing movement has only to be increased in some one direction, or to be lessened or stopped in the other directions, in order that it should become heliotropic, apheliotropic, \&c., as the case may be.'

\footnotetext{
1 The Power of Movement in Plants. London, 1880.
} 
So also, in discussing the connexion between circumnutation and positive heliotropism it is pointed out (p. 436) that:- 'A plant, when exposed to a lateral light, though this may be bright, commonly moves at first in a zigzag line, or even directly from the light; and this no doubt is due to its circumnutating at the time in a direction either opposite to the source of the light, or more or less transversely to it. As soon, however, as the direction of the circumnutating movement nearly coincides with that of the entering light, the plant bends in a straight course towards the light, if this is bright.'

In the case of dia-heliotropism, a similar explanation probably holds good; 'cotyledons and leaves place themselves so that their upper surfaces may be exposed to the light, and this movement is regulated, though not directly caused, by the direction whence the light proceeds' (p. 442).

In both orthotropic and diatropic organs, the final result aimed atthe equal illumination of the chlorophyll grains-is the same. Orthoheliotropic organs are symmetrical; dia-heliotropic organs are bi-symmetrical. In the latter case the position of the chlorophyll-containing tissue, not the epidermis merely, must determine finally the light position of the leaf, just as, in the former case, the symmetrical distribution of the chlorophyll tissue must finally determine whether the organ shall place itself parallel to the rays of light, or laterally with respect to them.

So far as the chlorophyll grains are concerned, the one-sided illumination of ortho-heliotropic organs corresponds almost exactly with the oblique illumination of dia-heliotropic organs. The only difference is that, in the one case, the whole of the chlorophyll grains on one side of the organ are exposed to the light, while the other side remains in obscurity; in the other case, the differential illumination takes place in each palisade cell in such a way that the chlorophyll grains on one side of the cell are more brightly illuminated than on the other. If this one-sided illumination is sufficient in the one case to bring about a regulation of the fundamental movements of circumnutation, it is fair to conclude that it is equally sufficient in the other.

In dia-heliotropic leaves which possess papillae, or other contrivances in their epidermal cells, capable of causing a convergence of the light rays, we should still have a one-sided illumination of the chlorophyll grains, probably more efficient than in leaves with flat-walled epidermal cells. It is quite possible, therefore, that in such cases the lens cells, although not absolutely necessary, may be of advantage, especially to shade plants, in bringing about the light perception. 


\section{SUMMARY.}

I. Haberlandt has shown that the cells of the upper epidermis of dia-heliotropic leaves are so constructed that they cause a convergence of the rays of light, and has suggested that they are functional as ocelli or primitive eyes, capable of setting up a stimulus which results in the heliotropic orientation of the leaf.

2. The central and peripheral areas of the layer of cytoplasm lining the basal walls of the epidermal cells are, according to Haberlandt's hypothesis, attuned to light of different intensities. When the leaf is in equilibrium, the central area is bright, the peripheral zone dark. When the light is oblique, these relations are altered, and it is this variation which sets up the stimulus by which the orientation of the leaf is brought about.

3. The efficiency of these lens cells is shown by the fact that in many leaves they are able to form clear images of objects focused through them, which may be easily seen under the microscope and can be photographed. It is not probable that the plant can perceive these images.

4. Haberlandt's hypothesis is open to criticism both on morphological and on physiological grounds. The phenomenon of the convergence of light by the cells of plants is, of very widespread occurrence. Not only the epidermal cells of leaves, but all cells which through turgidity assume a spherical or cylindrical form are capable of bringing it about.

5. Lens cells are present in many cases on leaves and other organs where there can be no question of their functioning in light perception.

6. The cells of the lower as well as the upper epidermis of leaves are in most cases capable of light convergence.

7. Special lens cells and lens-shaped thickenings of the cuticle often occur on the lower as well as the upper epidermis. The position of the lens-shaped thickenings of the cuticle in Garrya elliptica, which occur on both sides of the leaf, has no relation to the position of the epidermal cells.

8. According to the form and outline of the cell, the rays of light may be converged to a local point, a focal line, or to an irregular figure intermediate between these. Cells with very irregular outlines, as in Eranthis hyemalis, commonly have more than one series of converging rays. As many as three or more may be seen, each producing a bright spot of light.

9. Cylindrical cells which bring rays to a focal line are present on some orthotropic organs, such as stalks of leaves, pedicels of flowers, and hypocotyledons of seedlings, also on the long, narrow, non-sensitive leaves of such plants as Grasses, Hyacinth, Freesia, \&c.

Io. Papillate cells and lens-shaped thickenings of the cuticle are found on leaves which are not heliotropically sensitive.

II. The extent to which the phenomenon of light convergence is simply a result of cell-turgor and not an adaptation to light perception 
cannot be definitely determined, but it is suggested that the curvature of the lens cells of the epidermis may be found to bear some relation to the thickness of the cell-wall and cuticle. It is possible that this turgidity may be the starting-point for an adaptation to (I) either light perception or, as Haberlandt suggests, to (2) the more efficient illumination of the chlorophyll grains, or (3) both, but the evidence is not very conclusive.

I2. The papillate epidermal cells of petals exhibit a very pronounced convergence of light, with a clear differentiation on the basal wall of a central bright area, and a dark peripheral zone.

13. It is only in a very few leaves, where the cells are highly papillate, or where there is a well-marked local thickening of the cuticle, that we get the differential illumination of the basal wall required by Haberlandt's hypothesis. In some, it is not visible at all under any conditions, in others only when a small stop is used, and in a large number of leaves, probably the majority, there is no differential illumination as defined by Haberlandt, but only an unequal illumination of the basal wall when the light falls obliquely.

I4. The experiments which have been made upon the elimination of the lens function by submerging the leaves in water, or by covering them with a layer of paraffin oil, have given results which are so contradictory and unsatisfactory that a much more complete investigation is necessary before any definite conclusion can be based on them.

I5. In a few special cases, the lens cells appear to bring about a concentration of the light on the chlorophyll grains. In some leaves the general arrangement of the lens cells with respect to the chlorophyll grains seems to indicate that they are effective in promoting a more efficient illumination of the chlorophyll grains.

16. Haberlandt suggests that the stimulus may be brought about by the difference in pressure exerted by the light upon the cytoplasm; but this is so very slight that it is hardly probable it can be effective.

I7. There seems to be no good reason why the epidermal cells should be the percipient cells more than the chlorophyll-containing cells, except that the presence of chlorophyll would interfere with the incidence of the light upon the percipient protoplasm.

18. There is, however, some evidence that the perception of light is bound up with its absorption by the chlorophyll grains, in which case the palisade cells would be the percipient cells, and the chlorophyll grains with the cytoplasm in connexion with them the actual percipient organs. The evidence for this is as follows:- The heliotropic response depends mainly upon the quality of the light and not upon its intensity; the rays which are active are those which are absorbed by the chlorophyll; of these the more refrangible rays are the most important ; if it were merely the intensity and 
not the quality of the light, there seems to be no reason why the red and yellow rays should not be just as active as the blue and violet rays ; in the more refractive half of the spectrum the amount of light absorption is greatly in excess of that required for assimilation; when a chlorophyll screen is interposed between the leaves and the light, the heliotropic response either ceases altogether or is much reduced; in motile organisms, such as Euglena, the heliotactic response is bound up with the absorption of light by the pigment-spot; in the large majority of animal eyes the presence of a layer of pigment in connexion with the actual percipient organs seems to be necessary ; light exerts a very definite stimulus upon the chlorophyll bodies of some Algae and foliage leaves, resulting in their movement into positions in which they can be more effectively illuminated; why should not a similar stimulus bring about the orientation of the leaf itself, if the chlorophyll grains are incapable of movement ? the rays absorbed by the chlorophyll, which are functional in heliotropism, are the chemically active rays ; chemical changes taking place in the chlorophyll would afford a more satisfactory explanation of the origin of the stimulus than the pressure of light upon the cytoplasm.

19. With the exception possibly of the few special cases in which the light is concentrated upon the chlorophyll grains, there is no satisfactory evidence to show that the lens-shaped cells or local cuticular thickenings can be regarded as special adaptations, either for light perception or for the more efficient illumination of the chlorophyll grains, although it is possible that they may be of use for both purposes.

\section{EXPLANATION OF PLATES XXXI AND XXXII}

Illustrating Mr. Wager's paper on the Perception of Light in Plants.

\section{PLATE XXXI.}

The figures are reproduced from photographs taken by means of the Gordon photo-micrographic apparatus with the objectives of Leitz Nos. 3 and 4 , and oculars 4 and 8.

Fig. I. Reproduction of a photograph taken through the upper epidermal cells of Tradescantia fuminensis. Some of the cells are in much better focus than others.

Fig. 2. Special cells from the upper epidermis of Mesembryanthemum cordifolium. They contain a mucilaginous substance, and are equally well developed on the under side of the leaf.

Fig. 3. The special cells on the under side of the leaf of $M$. cordifolium, showing distant houses photographed through them. These special cells vary in size, and, being irregular in outline, do not usually give a circular disk of light.

Fig. 4. Lower epidermis of $M$. cordifolium, showing the special cells with highly refractive granular mucilaginous substance through which the light is shining. 
Fig. 5. Rays of light brought to a focus through the granules of mucilage shown in Fig. 4 . These granules interfere with the passage of light through the cells as a whole, and render the image more or less indistinct, as shown in Fig. 3.

Fig. 6. A geometrical figure with coloured segments photographed through the cells of Tradescantia fuminensis on an ortho-chromatic plate.

Fig. 7. Saxifraga Geum. Cells of upper epidermis, showing more or less central disks of light thrown on to the basal walls by the minute papillae which occur in the middle of the outer cell-walls.

Fig. 8. Shows the same disks of light moved laterally when the light is oblique.

Fig. 9. Shows the extreme lateral movement of which they are capable when the rays which fall upon the leaf are still more oblique.

Fig. 10. Upper epidermal cells of Prumus lauro-cerasus. The photograph shows the illumination of the basal walls by light which has passed through a small diaphragm $\frac{3}{16}$ " in diameter. There is no differential illumination of the basal wall. The outer walls of the cells are flat, the inner walls slightly curved. In spite of this absence of differential illumination, the leaves undergo a definite orientation into the position of equilibrium as regards the light.

Fig. II. Aspidistra lurida. Upper epidermal cells showing images of a six-sided figure photographed through the transparent nuclei.

Fig. I2. Zebrina pendula. Image of a cabinet photograph, taken through the papillate projection on the outer cell-wall, and focused very nearly on the basal wall in each cell.

\section{PLATE XXXII.}

Fig. I3. Tradescantia fuminensis. Basal walls of epidermal cells showing that convergence of light produces no differential illumination.

Fig. I4. The same preparation. Light focused slightly below the basal walls after passing through a small diaphragm opening.

Fig. I5. The same preparation, under same conditions, but focused at some distance below the basal walls. At this level there is a distinct differential illumination as shown by the separate irregular disks of light.

Fig. 16. Basal walls of the cells in the same preparation when light falls obliquely upon the outer walls. Half of each basal wall is in the light and half in darkness.

Fig. I7. Upper epidermis of Eranthis hyemalis. Shows the irregular light areas below the basal walls of the epidermal cells when allowed to fall upon the outer curved walls through a small diaphragm opening. Here and there in these light areas in each cell are to be observed clearer circular disks of light, due to more pronounced curvature of the cells. Each one of these is capable of forming an image of an object near it.

Fig. 18. Basal walls of papillate epidermal cells of the petals of Phlox showing a clear disk of light in the centre of each cell.

Fig. 19. Elongate cells of epidermis of Tradescantia virginica showing lines of light brought to a focus on the basal walls. The guard cells of the stomata also bring about a convergence.

Fig. 20. Elongate cells of epidermis of Iris alata showing very bright illumination of basal walls when light is allowed to pass through a small diaphragm opening.

Fig. 2I. Cells of the upper epidermis of Convallaria majalis showing bands of light which are brought to a focus near the basal walls when a small diaphragm opening is used.

Fig. 22. Inner epidermal cells of the sheathing leaf of Avena sativa showing the image of a pipe focused on or near the basal walls. At the ends of the cells, owing to a more prominent curvature of the outer walls, the outline of the pipe is distinctly seen, but between these there is a more or less continuous dark line which represents the pipe.

Fig. 23. Epidermal cells of the leaf of Garrya elliptica showing the special lens-shaped thickenings of the cuticle. These are distributed more or less regularly over the whole surface of the leaf, independently of the position of the cells. Some of the thickenings occur exactly over the walls which separate neighbouring cells.

Fig. 24. The same preparation showing the image of a cross brought to a focus near the basal walls of the epidermal cells. 


\section{Annats of Botany}
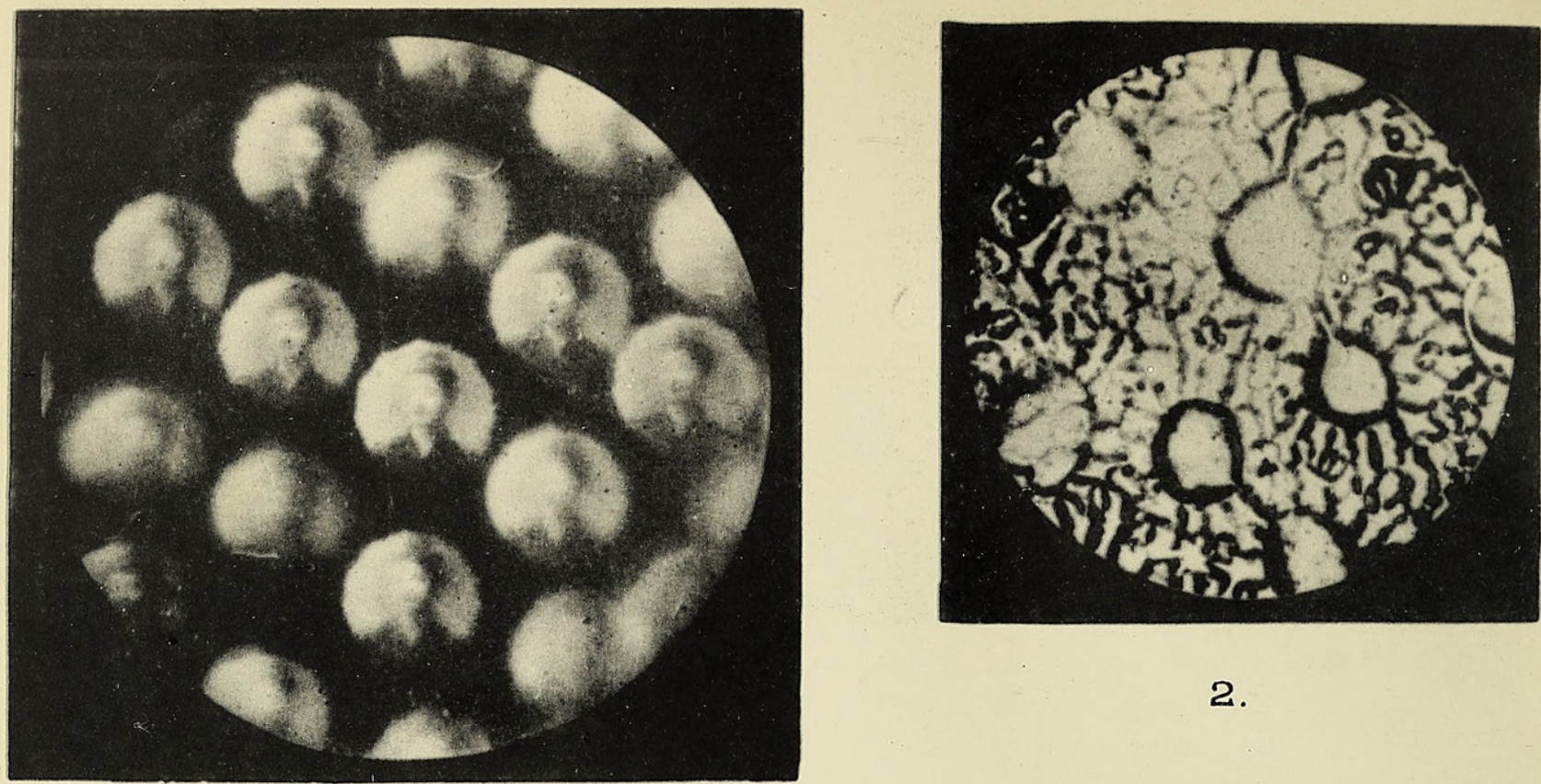

1.

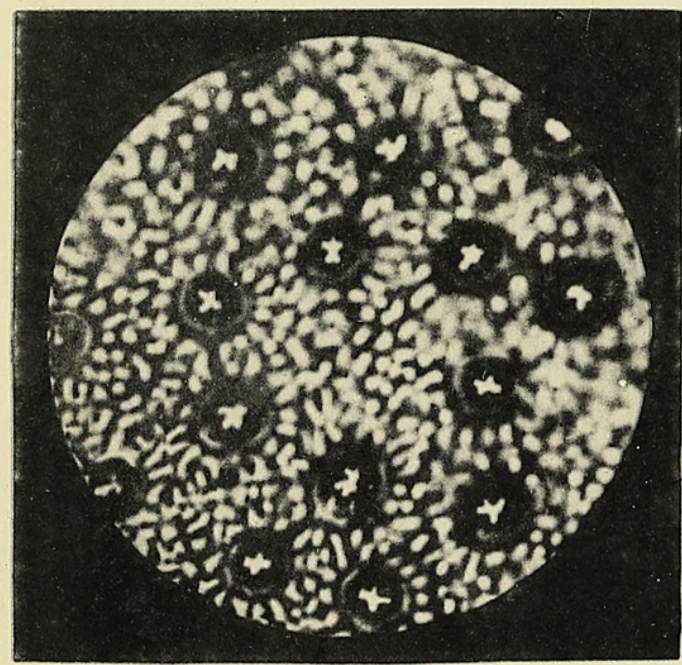

4.

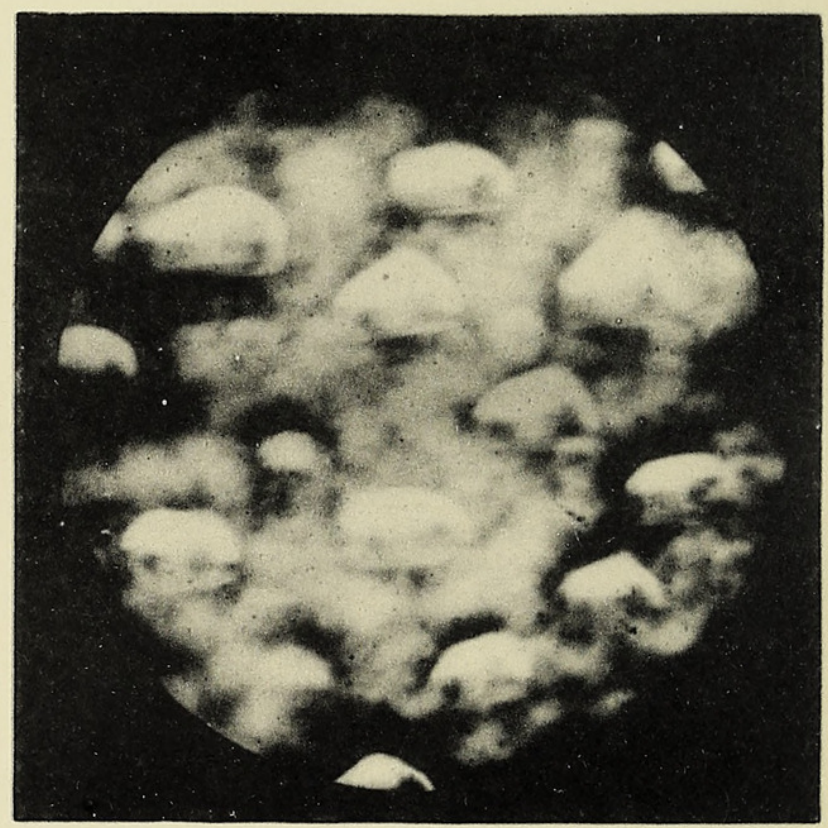

3.

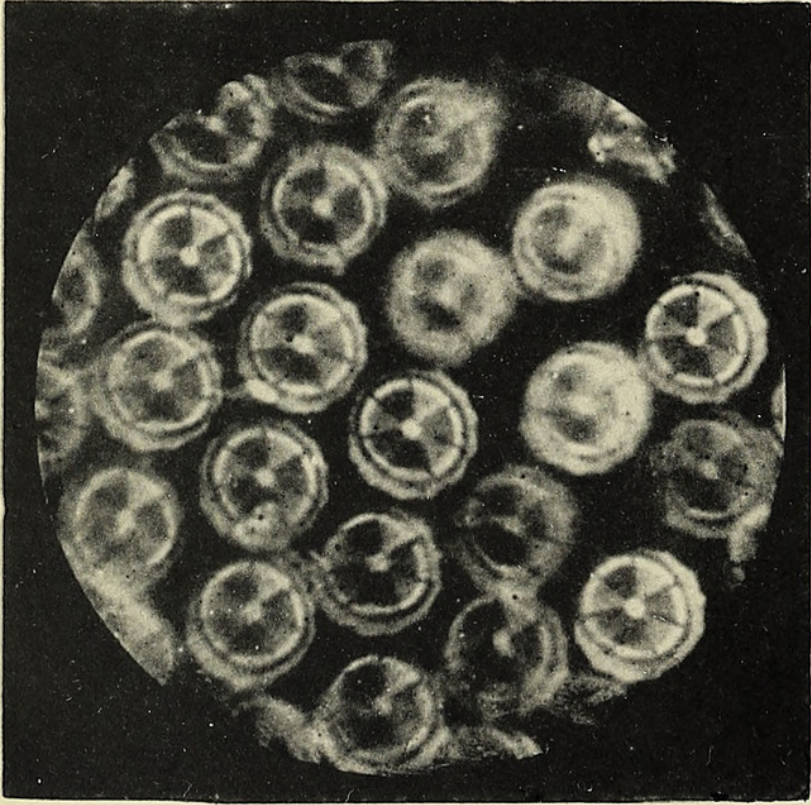

6.

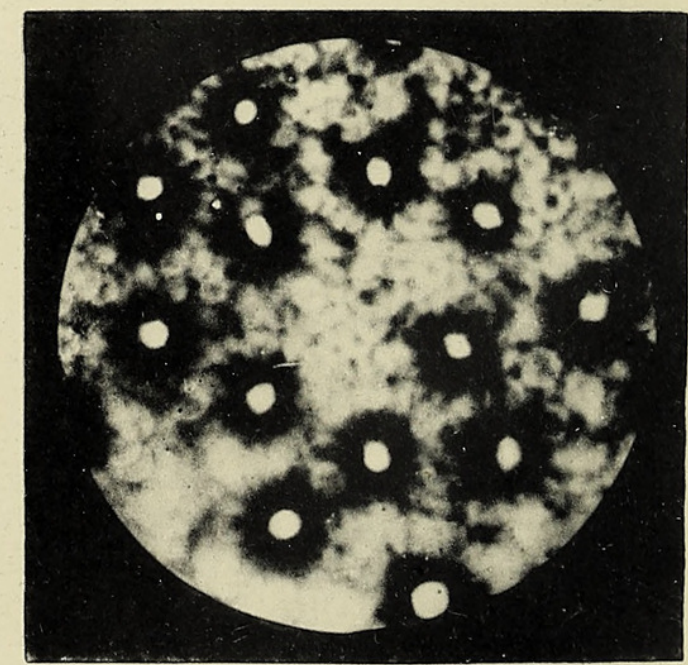

5. 


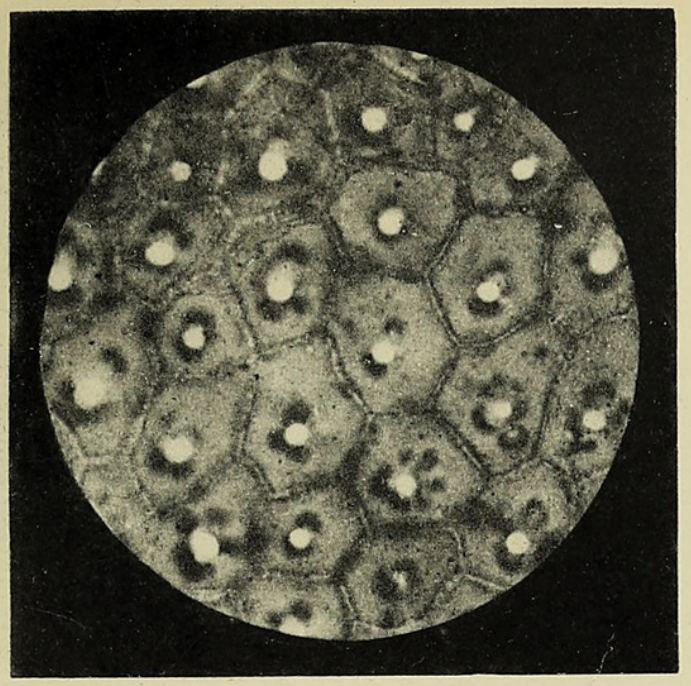

7.

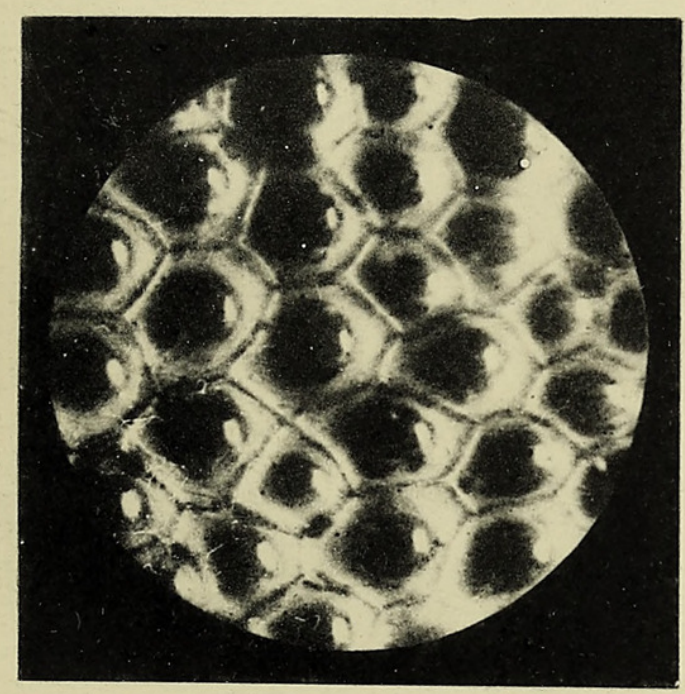

9.

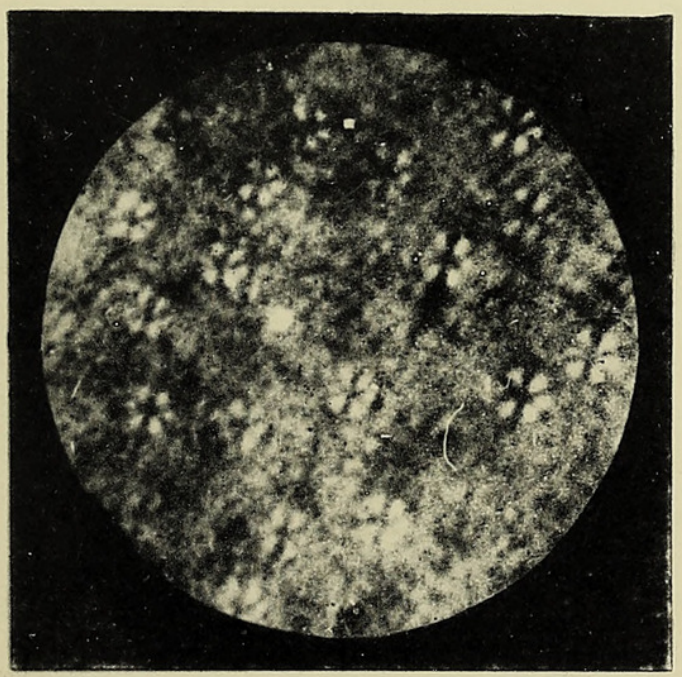

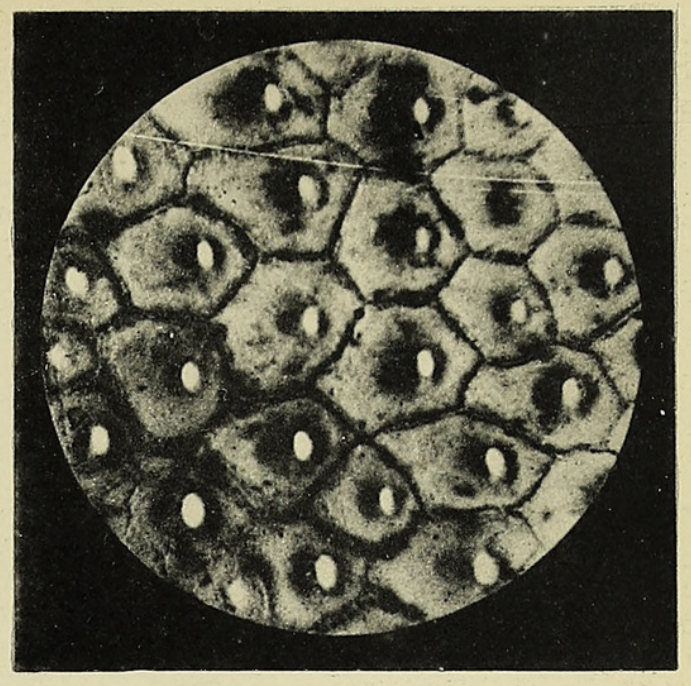

8.

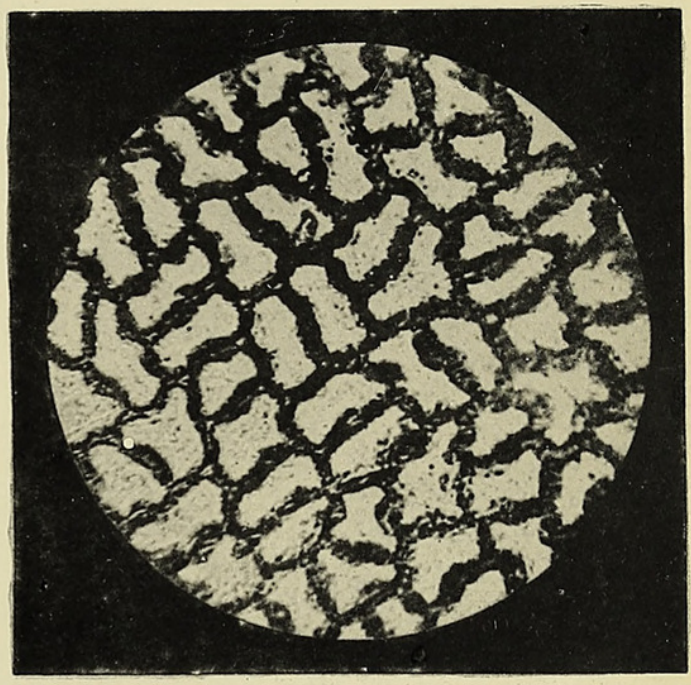

10

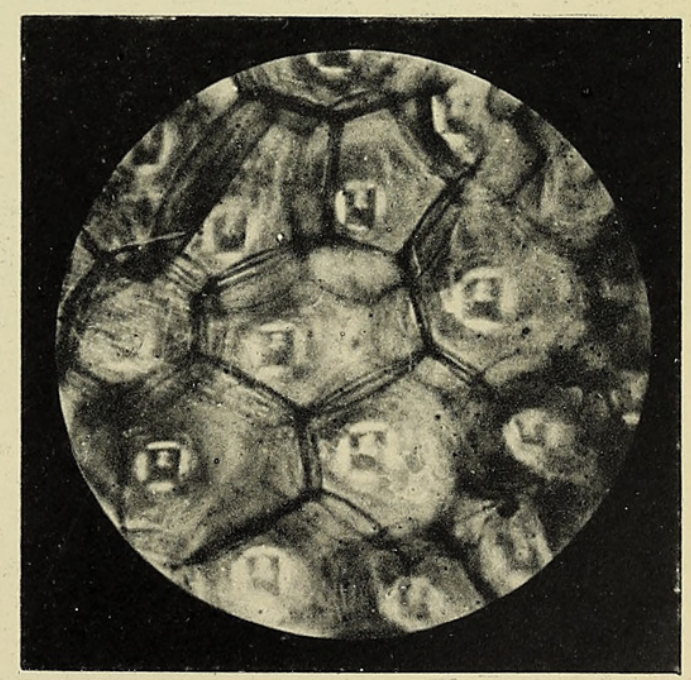

12. 
Anrats of Botany,

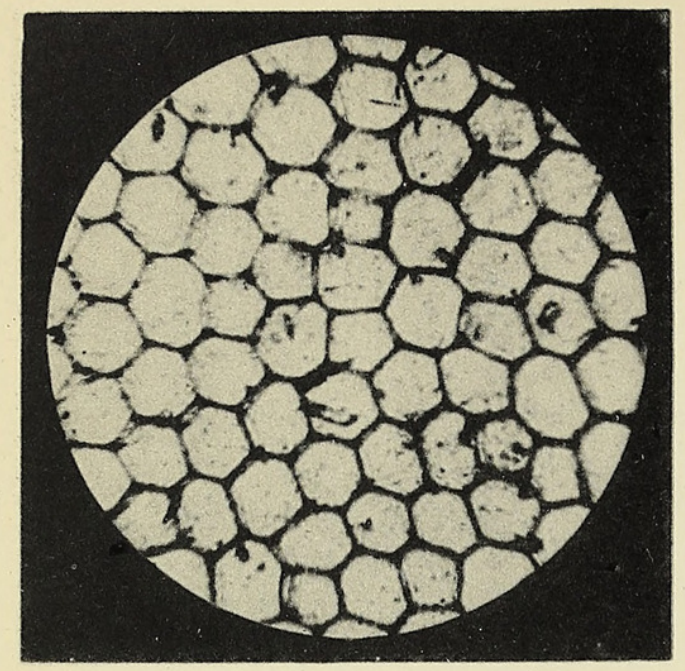

13.

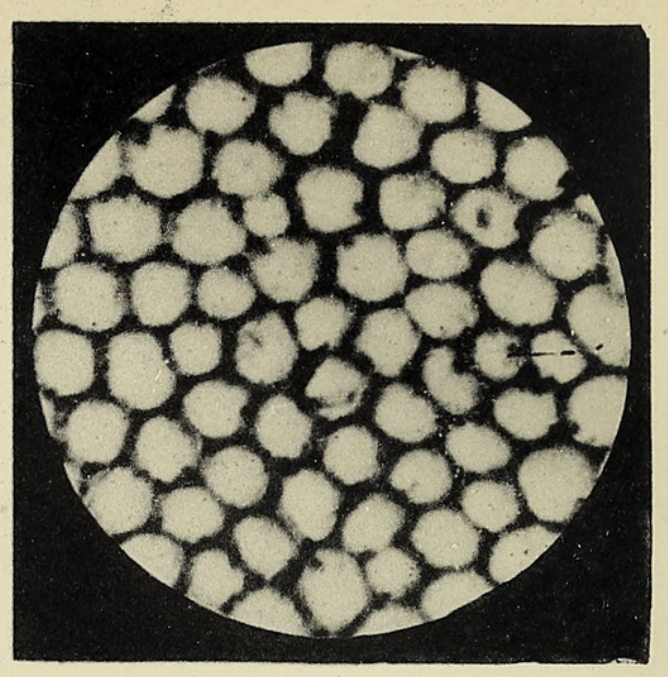

14 .

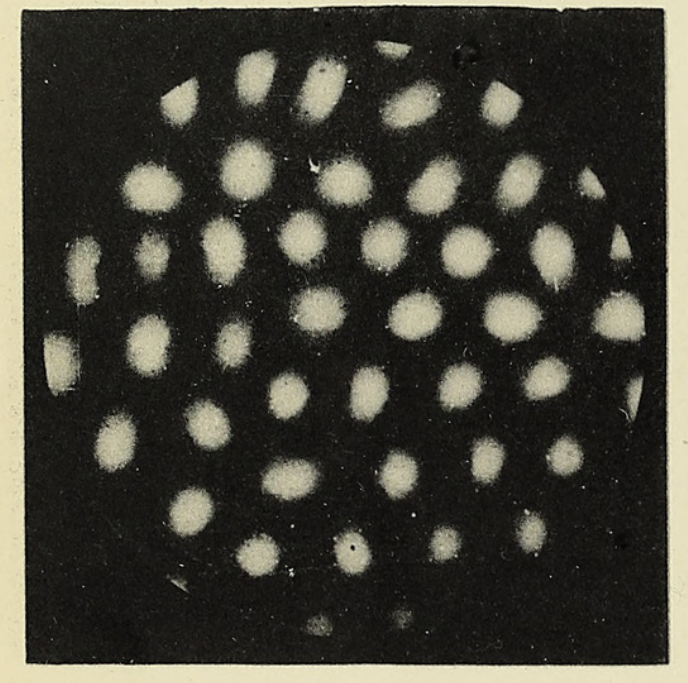

15.

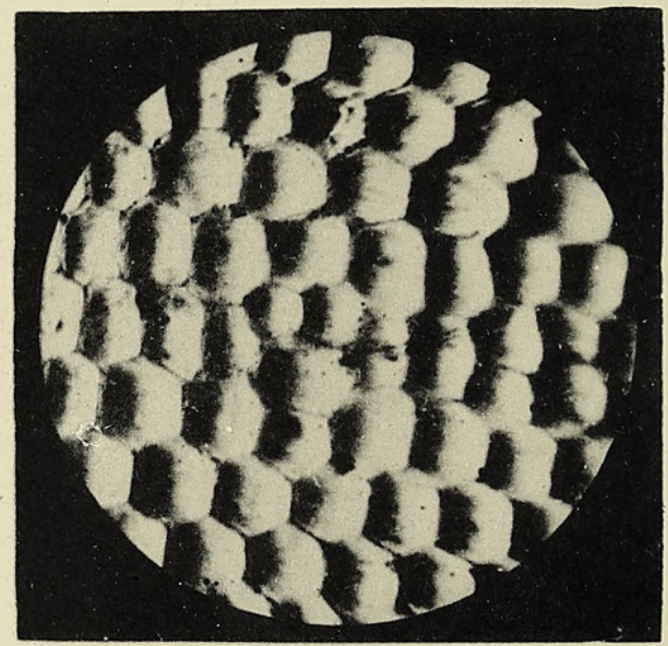

16.

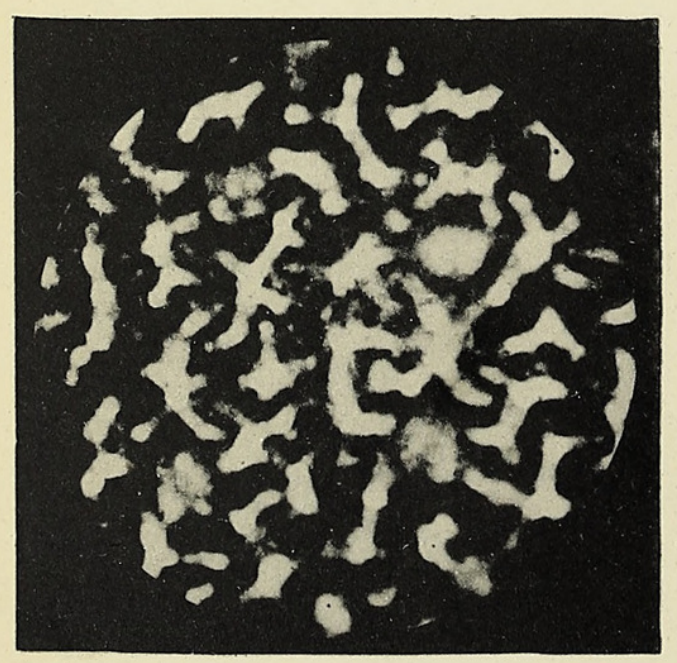

17.

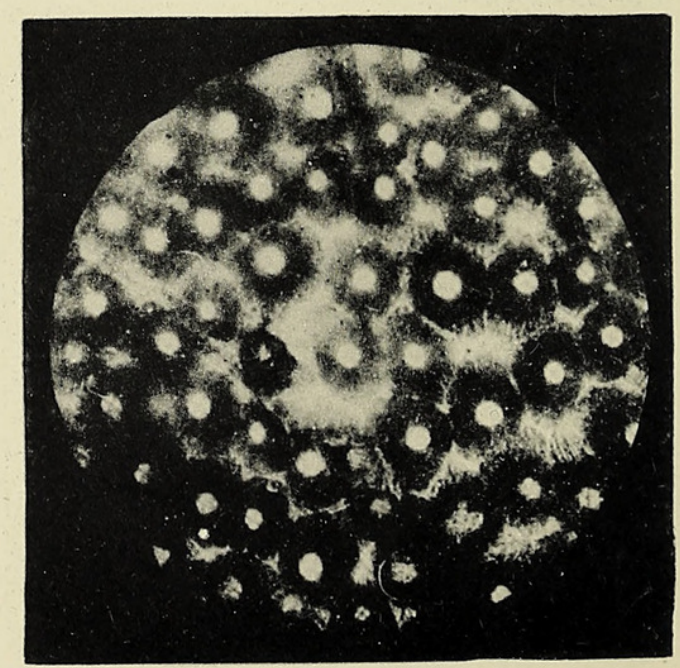

18. 


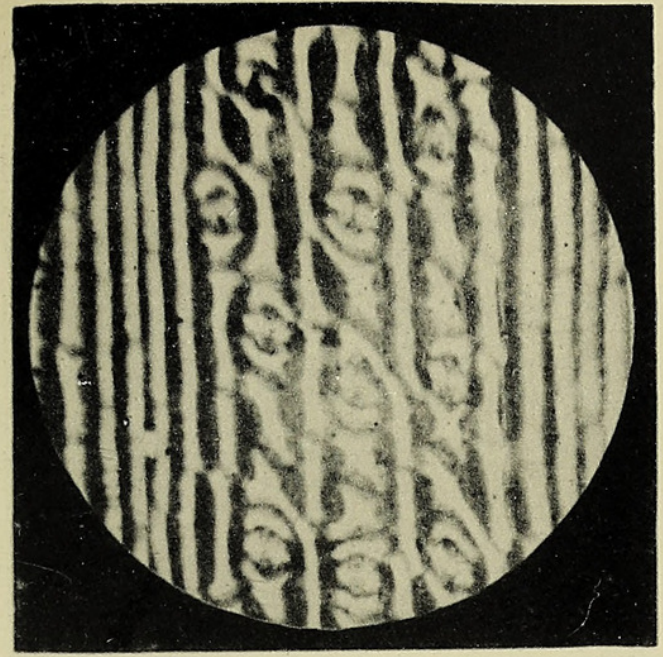

19.

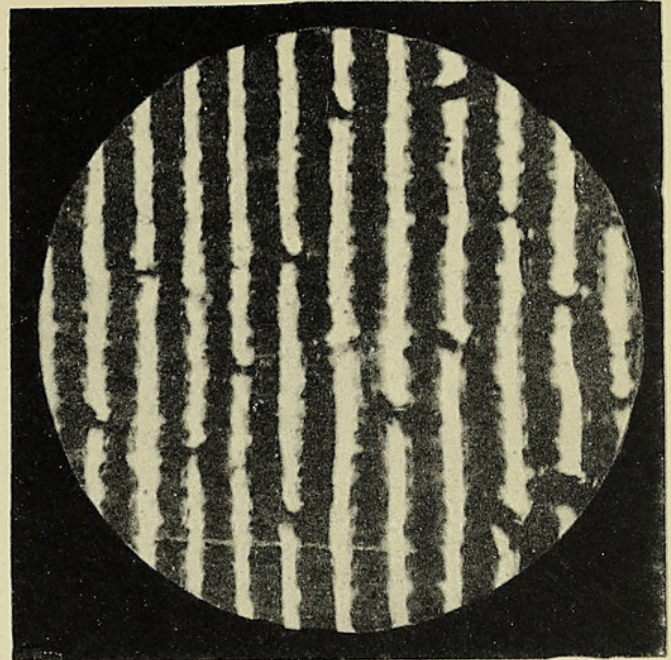

20.

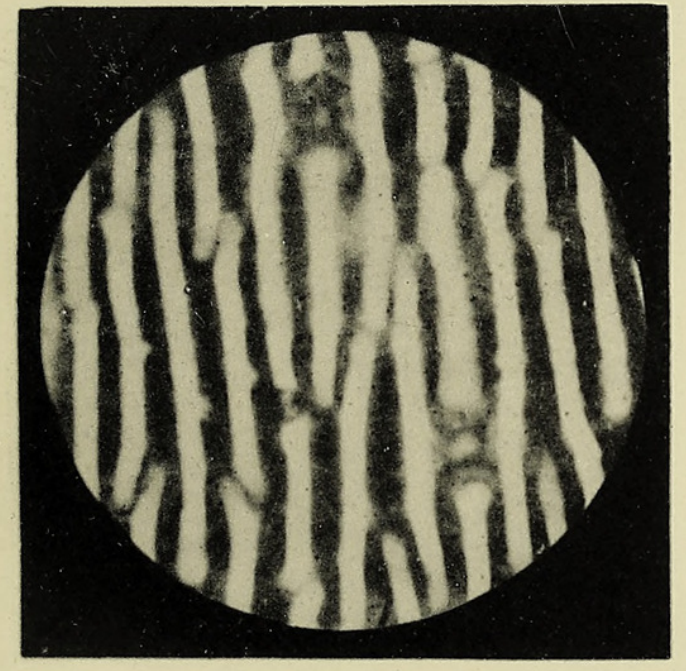

21.

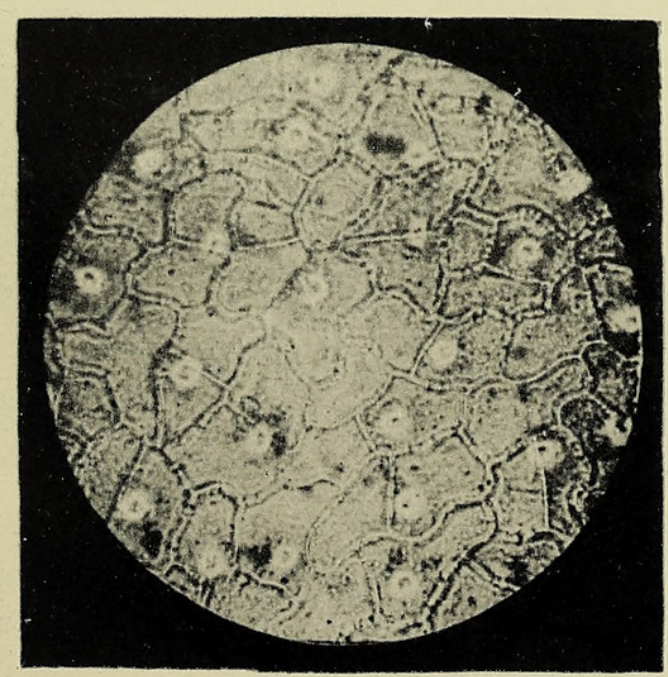

23.

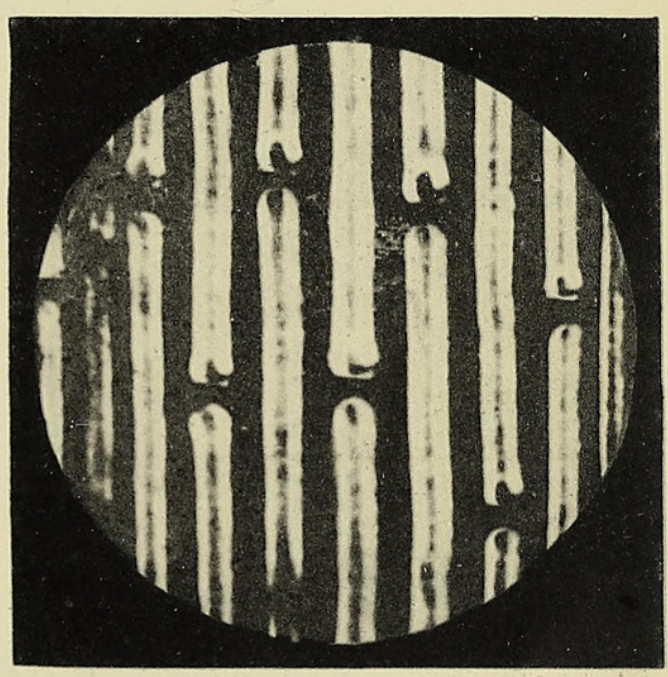

22 .

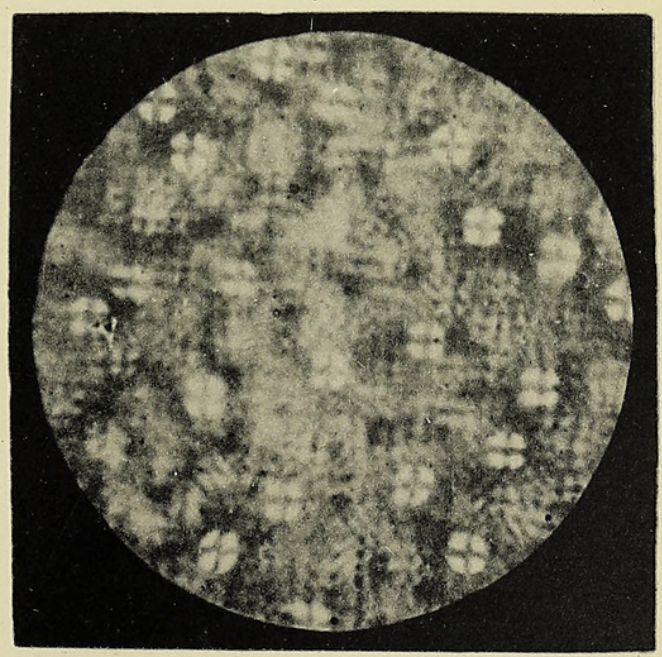

24 


\section{$2 \mathrm{BHL}$ Biodiversity Heritage Library}

Wager, Harold W. T. 1909. "The perception of light in plants." Annals of botany 23, 459-489. https://doi.org/10.1093/oxfordjournals.aob.a089231.

View This Item Online: https://www.biodiversitylibrary.org/item/236540

DOI: https://doi.org/10.1093/oxfordjournals.aob.a089231

Permalink: https://www.biodiversitylibrary.org/partpdf/318966

\section{Holding Institution}

Smithsonian Libraries

\section{Sponsored by}

Biodiversity Heritage Library

\section{Copyright \& Reuse}

Copyright Status: Not in copyright. The BHL knows of no copyright restrictions on this item.

This document was created from content at the Biodiversity Heritage Library, the world's largest open access digital library for biodiversity literature and archives. Visit BHL at https://www.biodiversitylibrary.org. 